INTER NATIONAL MONETARY FUND
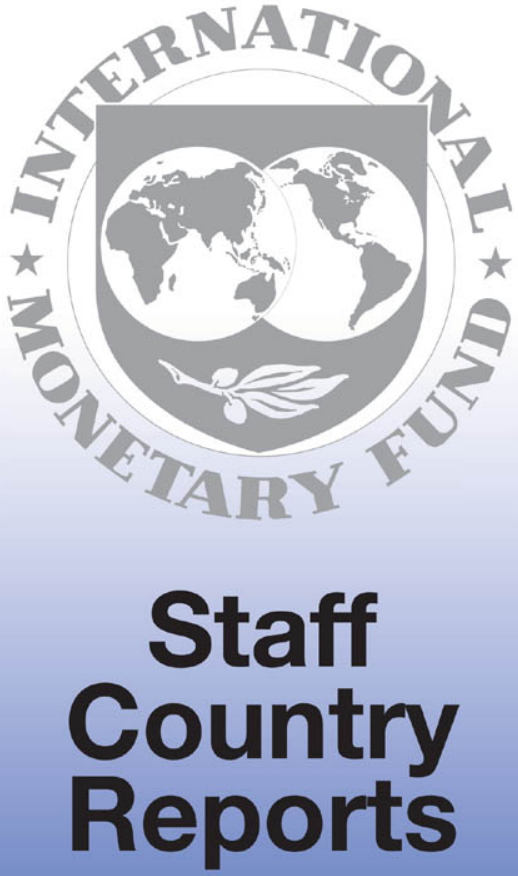


\section{Sweden: Financial Sector Assessment Program Update-Detailed Assessment of Observance on NASDAQ OMX DM Observance of the CPSS-IOSCO Recommendations for Central Counterparties}

This Detailed Assessment of Observance on NASDAQ OMX DM Observance of the CPSSIOSCO Recommendations for Central Counterparties was prepared by a staff team of the International Monetary Fund as background documentation for the periodic consultation with the member country. It is based on the information available at the time it was completed in September, 2011. The views expressed in this document are those of the staff team and do not necessarily reflect the views of the government of Sweden or the Executive Board of the IMF.

The policy of publication of staff reports and other documents by the IMF allows for the deletion of market-sensitive information.

Copies of this report are available to the public from

International Monetary Fund $\bullet$ Publication Services

$70019^{\text {th }}$ Street, N.W. $\bullet$ Washington, D.C. 20431

Telephone: (202) 623-7430 • Telefax: (202) 623-7201

E-mail: publications@imf.org Internet: http://www.imf.org

\section{International Monetary Fund \\ Washington, D.C.}


FinANCIAL SECTOR ASSESSMENT PROGRAM UpdATE

\section{SWEDEN}

\section{NASDAQ OMX DM OBSERVANCE OF THE CPSS-IOSCO RECOMMENDATIONS FOR CENTRAL COUNTERPARTIES}

\section{DETAILED ASSESSMENT OF OBSERVANCE}

SEPTEMBER 2011

INTERNATIONAL MONETARY FUND

MONETARY AND CAPITAL MARKETS DEPARTMENT 
Glossary $\underline{3}$

I. Information and Methodology Used for Assessment ..................................................... $\underline{5}$

II. Institutional and Market Structure — Overview............................................................. $\underline{5}$

III. Regulatory Framework and Oversight............................................................................

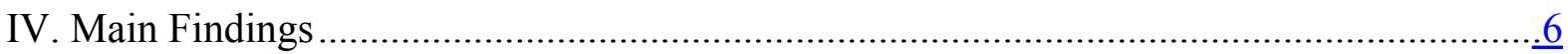

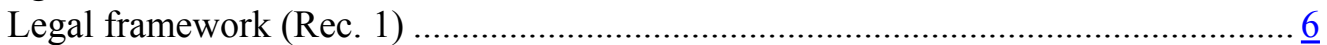

Participation requirements (Rec. 2) …................................................................ $\frac{7}{7}$

Financial risk management (Rec. $3-6)$................................................................ $\frac{7}{7}$

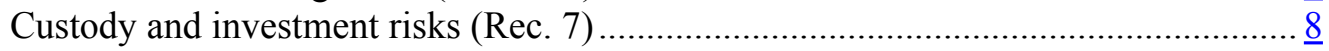

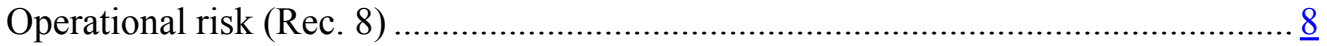

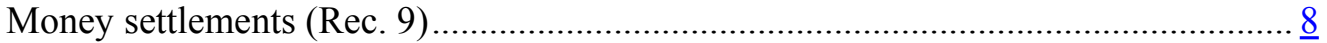

Physical deliveries (Rec. 10) .................................................................................. $\frac{8}{8}$

Risks in links between CCP (Rec. 11) .............................................................. $\frac{8}{8}$

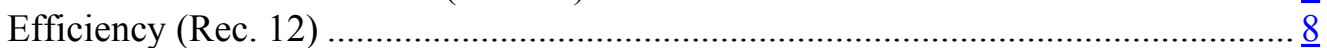

Governance (Rec. 13) ............................................................................. $\frac{8}{8}$

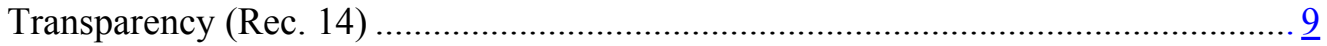

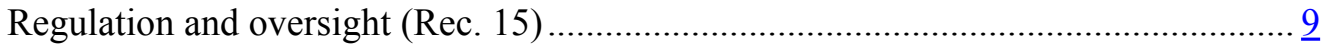

V. Authorities' Response to the Assessment ......................................................................

Tables

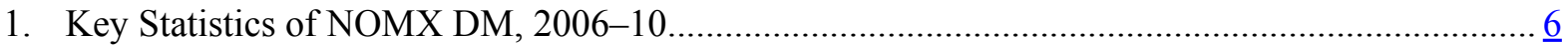

2. Detailed Assessment of Observance of NASDAQ OMX Clearing of the

CPSS-IOSCO Recommendations for Central Counterparties ………………………………...... 10

3. Summary of the Detailed Assessment of Observance of NOMX DM with the CPSS-IOSCO Recommendations for Central Counterparties .............................................. 40

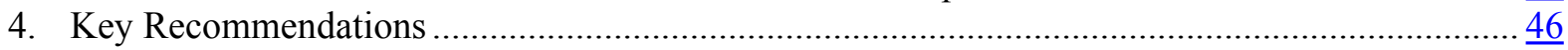

5. Additional Recommendations........................................................................................... 


\section{GLOSSARY}

BCP

$\mathrm{CCAB}$

$\mathrm{CCP}$

CESR

CFM

CPSS

CSDs

DCM

DVP

ECB

EMIR

ERM

EU

FI

FSA

FSAP

GCM

GITS

IMF

IOSCO

IT

MOF

MOU

NCM

NOK

NOMX DM

NOMX COM

NOMX STO

OMXCI

OTC

$\mathrm{RB}$

RCCPs

RIX

RMD

R\&R

SEK

VP

VPS
Business Continuity Plan

Clearing Control $\mathrm{AB}$

Central Counterparty

Committee of European Securities Regulators

Cash Flow Margin

Committee on Payment and Settlement Systems

Centralized Securities Depository

Direct Clearing Member

Delivery-versus-Payment

European System of Central Banks

European Market Infrastructures Regulation

Enterprise Risk Management

European Union

Finansinspektionen

Financial Supervisory Authority

Financial Sector Assessment Program

General Clearing Member

Global IT Services

International Monetary Fund

International Organization of Securities Commission

Information Technology

Ministry of Finance

Memorandum of understanding

Non-Clearing Member

Norwegian krona

NASDAQ OMX Derivatives Markets

NASDAQ OMX Commodities Markets

NASDAQ OMX Stockholm

OMX Capital Insurance AG

Over-the-Counter

Riksbank

Recommendation for Central Counterparties

Riksbank's Payment System

Risk Management Department

Rules and Regulations

Swedish Kronor

Danish securities settlement system

Norwegian securities settlement system 


\section{EXECUTIVE SUMMARY}

NASDAQ OMX Derivatives Markets (NOMX DM) is a central counterparty (CCP) that clears equity, fixed income derivatives and repos. It clears both exchange traded and over-the-counter (OTC) transactions denominated in SEK, DKK, NOK, EUR, but the bulk of the products are in SEK. NOMX DM exhibits several positive characteristics such as a clear separation of lines, skilled people and a service of segregation account which is nearly unique.

\section{However, several features are of concern. NASDAQ OMX Stockholm (NOMX STO)} comprises both NOMX DM and another CCP that clears commodities products in a branch located in Norway. Since both CCPs share the same financial protection to face extreme losses, difficulties in one of them would spillover on to the other one. The financial resources set aside by NOMX STO to face extreme losses, in the absence of a mutualized guarantee fund, are ring-fenced through a highly complex mechanism. This structure may result in legal uncertainty and would create delay for NOMX DM in having access to the funds in case of need. More generally the financial resources do not provide a sufficiently reliable liquidity level. In view of the legal situation which makes it possible for CCPs to have access to intraday credit and the deposit facility with RB, it would be beneficiary for NOMX DM to operationalize these possibilities so that it can use them in case of needs. Also, the set up for collecting margins is totally outsourced to Custodian Institutions which are not subject to an effective control by NOMX DM.

Due to the upcoming European Union legislation (European Market Infrastructures Regulation (EMIR)), NOMX DM will be compelled to implement significant changes in its current set up which should address most of these identified areas of weaknesses. 


\section{INFORMATION AND METHODOLOGY USED FOR ASSESSMENT}

1. The assessment of NOMX DM against the CPSS/IOSCO Recommendations for Central Counterparties (RCCPs) was undertaken in the context of the IMF's Financial Sector Assessment Program (FSAP) Update for Sweden, March 9-22, 2011. ${ }^{1}$ Prior to the mission, NOMX DM conducted a comprehensive and clear self-assessment following the methodology of the RCCPs published in 2004. The assessor also benefited from discussions with FI, RB, as well as NOMX DM senior management and staff, and some participants in the system. The Swedish authorities were fully cooperative and all relevant documentation to fulfill the assessment was made readily available. Relevant authorities and the operator of the system have been very cooperative in providing supplemental information and organizing additional meetings, when required.

\section{InStitutional AND MARKET STRUCTURE-OVERVIEW}

2. NOMX DM, as the only CCP based in Sweden, provides CCP services for equity and fixed income derivatives, as well as repos transactions since 2010. It clears products issued in SEK, DKK, NOK, EUR, but the bulk of the products are in SEK. Products cleared are either exchange traded on Nordic markets operated by NOMX Group or OTC traded but highly standardized.

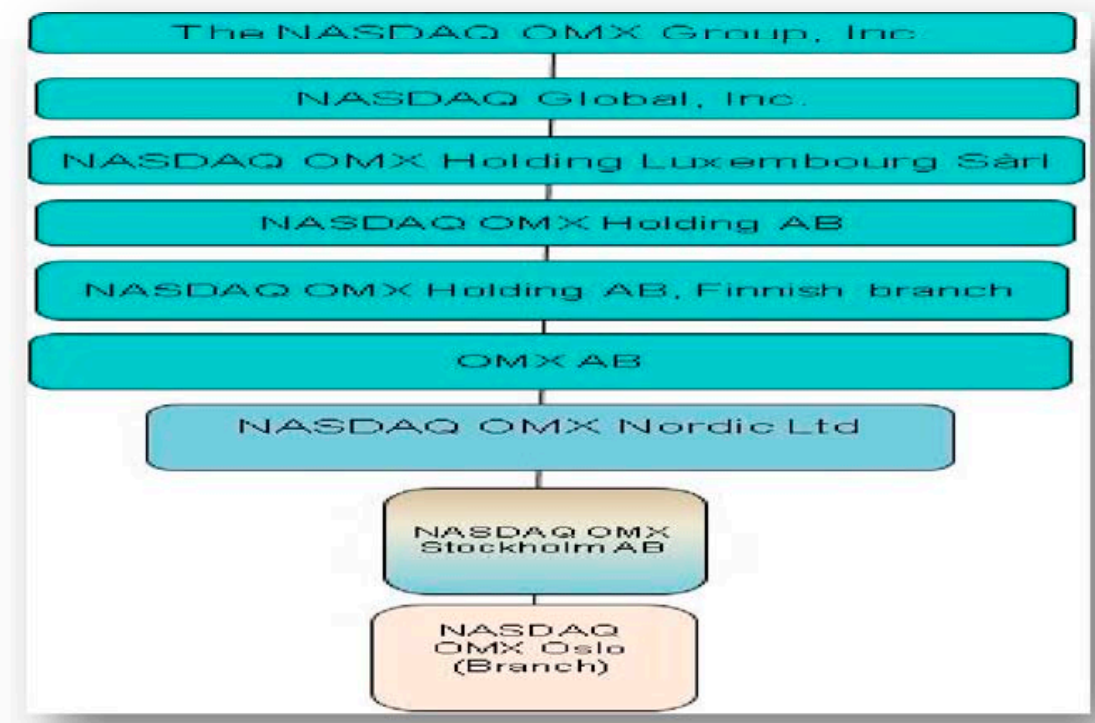

3. NOMX DM has no specific legal existence, but is included within NOMX STO which operates the Swedish stock exchange. NOMX STO is a subsidiary of NOMX Nordic Limited which belongs to the NOMX Group, an international group that offers services for

\footnotetext{
${ }^{1}$ The assessment was prepared by Philippe Troussard from Banque de France.
} 
trading securities in more than 50 countries. In 2008, NOMX Group acquired Nord Pool Clearing, a CCP in power derivatives and other contracts traded on the Nord Pool power exchange in Norway. In December 2009, Nord Pool Clearing was incorporated in NOMX STO and its activities have been conducted since then as a Norwegian branch of NOMX STO (see chart above and figures below).

\section{Table 1. Sweden: Key Statistics of NOMX DM, 2006-10}

\begin{tabular}{lrrrrr}
\hline & 2006 & 2007 & 2008 & 2009 & 2010 \\
\hline 1.Number of transactions (thousands) & & & & & \\
1.1 Equities Derivatives & 788 & 765 & 696 & 762 & 870 \\
1.2 Equity Index Derivatives & 1.908 & 3.880 & 6.683 & 7.832 & 8.643 \\
1.3 Fixed Income Derivatives & 31 & 40 & 53 & 38 & 48 \\
TOTAL & 2.727 & 4.685 & 7.432 & 8.632 & 9.561 \\
2. Value of transactions (SEK billions) & 4.791 & 7.490 & 6.605 & 6.560 & 6.623 \\
3. Average daily value of transactions (SEK & 18 & 29 & 25 & 20 & 26 \\
billions) & & & & & 119 \\
4. Peak value of transactions (SEK billions) & 109 & 152 & 116 & 101 & 46 \\
5. Number of clearing members & 31 & 37 & 37 & 48 & 46 \\
$\quad$ of which: & & & & & \\
5.1 Foreign clearing members & 9 & 12 & 15 & 26 & 24 \\
6. Clearing fund (EUR millions) & 0 & 0 & 0 & 0 & 0 \\
\hline Source: RB. & & & & &
\end{tabular}

\section{REGULATORY FRAMEWORK AND OVERSIGHT}

4. NOMX STO is authorized as an exchange and has a permit from FI to conduct clearing operations in accordance with the Securities Market Act. NOMX STO is subject to supervision by Finansinspektionen (FI). As NOMX DM is a secondary legal name (brandname) for NOMX STO, the same legal status and supervision applies to NOMX DM as to NOMX STO. NOMX DM is also subject to the Riksbank's (RB) oversight. Both FI and $\mathrm{RB}$ cooperate to monitor NOMX DM activities. In conducting their supervisory and oversight responsibilities regarding NOMX DM, FI and RB apply the RCCPs.

\section{MAIn FindingS}

\section{Legal framework (Rec. 1)}

5. NOMX DM clearing activities are governed by a consistent and solid set of laws, rules, and contractual provisions. In particular, this legal framework supports the enforcement of transactions, netting procedures, protection of customer assets, and deliveryversus-payment (DvP) with finality. There are adequate rules for addressing the event of a participant default, including the effective use of collateral, and these rules can legally be enforced. 


\section{Participation requirements (Rec. 2)}

\section{NOMX DM access and exit criteria are well defined and publicly disclosed.}

NOMX DM requirements for participants' financial resources and operational reliability are defined according to membership category. All members must be regulated entities and must have a minimum capital requirement. They also must have adequate operational capability. NOMX DM has procedures in place to monitor participation requirements are met on an ongoing basis. However, direct pledge end customers, which are characterized by having direct relationships with NOMX DM, are not subject to specific requirements though NOMX DM has direct counterparty risk with them. NOMX DM should set participation requirements for direct pledge end customers.

\section{Financial risk management (Rec. 3-6)}

\section{NOMX DM has a comprehensive risk management framework composed of} objectives, measures, and tools. NOMX DM monitors its participants' exposure on a real time basis, and conducts intraday calls for margins when a specific threshold is hit. NOMX DM regularly validates coverage of the models and parameters used to determine margin requirements.

\section{In the absence of a mutualized default fund, the financial resources set aside to} face extreme losses are brought by NOMX STO itself, which might create moral hazard. They are ring-fenced, but through a highly complex mechanism structure which raises several concerns: high complexity which potentially may result in legal uncertainty and delay in having access to the funds in case of needs, thus a lack of liquidity. Within NOMX STO, both trading and clearing activities are conducted and two different clearing activities are conducted under two different brand names: clearing of financial derivatives by NOMX DM and clearing of commodities products by NASDAQ OMX Commodities Markets (NOMX COM). Though both CCPs do not share the same participants, they share the same "regulatory capital" dedicated to cover losses in case of a member's default. As a consequence, difficulties in one of them could have spillover effects on to the other one. The financial resources do not provide a sufficiently reliable liquidity level. NOMX DM accepts as collateral bank guarantees which by definition are not liquid resources. In addition, these bank guarantees are provided by banks which are also NOMX DM's members, while two of them are the sole liquidity providers. It should be noted that the interest of access to central bank credit is enhanced by the fact that the highly concentrated nature of the Swedish banking sector makes it nearly impossible for NOMX DM to sufficiently diversify its liquidity providers.

\section{NOMX DM default procedures are clearly stated in the system's rules and}

published on its website. The structure of customer segregation under the agent clearing model highly facilitates the transfer of collateral and positions of end-customers in case of a member's default. 


\section{Custody and investment risks (Rec. 7)}

10. NOMX DM relies on custodian banks, which are also CCP's members, for collection of collateral, valuation, application of haircuts, compliance with concentration limits. This current set up is risky as NOMX DM may not have access to the collateral in case of a custodian default. In addition NOMX DM does not sufficiently monitor the activities of the custodians. NOMX DM has no real time knowledge on the composition of collateral collected as well as no ex post information on it, except when it conducts a test once in a year.

\section{Operational risk (Rec. 8)}

11. NOMX DM identifies and analyses source of operational risks through a framework also encompassing outsourced operations. NOMX DM has two mirrored sites and a Business Continuity Plan (BCP) in place which is regularly tested. The operational risk is under the scope of Internal Audit.

\section{Money settlements (Rec. 9)}

12. NOMX DM uses the central bank model for SEK and DKK which represent 99 percent of settlement flows. Payments made and received by NOMX DM are effected on its accounts with RB and Nationalbank. Payments made and received through commercial banks are negligible and not relevant from a risk management perspective.

Physical deliveries (Rec. 10)

13. NOMX DM deliveries of securities are carried out through securities settlement systems that ensure DVP, thus eliminating the risk of payment without delivery, and its obligations for physical delivery are clearly stated

Risks in links between CCP (Rec. 11)

This recommendation is not applicable since there is no link in place.

Efficiency (Rec. 12)

14. NOMX DM reviews its pricing and service levels, as well as capacity level on a regular basis and it performs periodic benchmarking studies with other CCPs in other European countries to assess its costs and fees.

Governance (Rec. 13)

15. Governance arrangements of NOMX DM are clearly specified and information about them is publicly available on the website. They support robust risk management by a 
separation in the reporting lines between risk management and other operations. In both the Clearing risk committee and the Default committee, the head of risk management has a veto power. NOMX DM does not sufficiently request feedback on its clearing services from members on a multilateral basis. Participants are not represented on NOMX STO Board or through participant committees within NOMX DM that would bring their specific perspectives and interests.

\section{Transparency (Rec. 14)}

16. NOMX DM discloses to its clearing members and other market participants its rules as well as relevant documentation in an easy to understand style on its website. These rules and documents cover, among other things, the rights and obligations of participants, procedures for handling risks, and fees for using its services. NOMX DM has published a comprehensive self-assessment following the RCCPs assessment methodology.

\section{Regulation and oversight (Rec. 15)}

17. The legal basis for an effective regulation and oversight exists. FI and RB have the ability and the resources to carry out regulation and oversight activities effectively. The responsibilities as well as roles and major policies of FI and RB are clearly defined and publicly disclosed. FI and RB require NOMX DM to provide information necessary for regulation and oversight. However, they do not have a sufficient level of information and understanding of the activities conducted by NOMX COM which would be required by the spillover effects this latter one could have on NOMX STO and notably NOMX DM. FI and $\mathrm{RB}$ cooperate with each other and with other relevant authorities, but efficiency gains may be reaped by more effective cooperation and by adopting a more risk based approach. 


\section{Table 2. Detailed Assessment of Observance of NASDAQ OMX Clearing of the CPSS-IOSCO Recommendations for Central Counterparties}

\begin{tabular}{|c|c|}
\hline Recommendation 1. & $\begin{array}{l}\text { A CCP should have a well founded, transparent and enforceable legal framework for } \\
\text { each aspect of its activities in all relevant jurisdictions. }\end{array}$ \\
\hline Description & 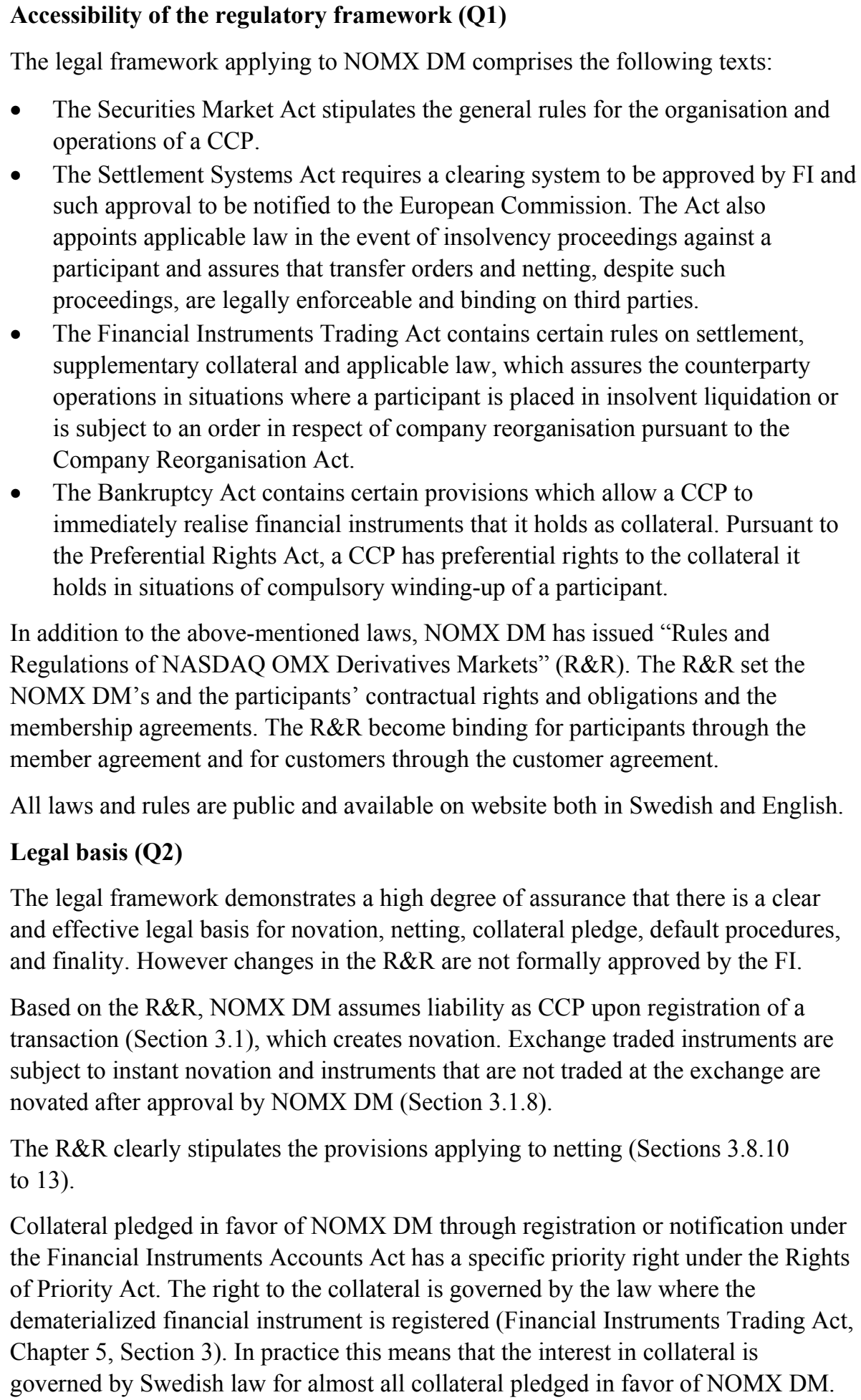 \\
\hline
\end{tabular}


In the event NOMX DM is placed in insolvent liquidation, all contracts shall be settled immediately and any and all of the exchange's and the counterparty's obligations under the R\&R shall be set off (Section 1.10.1). This is also supported by the Financial Instruments Trading Act.

In case of a member's or customer's default or where it can be anticipated that a member or customer will default, NOMX DM has access to a range of actions (see Recommendation 6 for more details).

NOMX DM is a designated settlement system under the EU Settlement Finality Directive which ensures finality of transactions.

The R\&R stipulate that a transfer order with respect to cash settlement or delivery shall be deemed placed in the clearing system upon receipt of a request by NOMX DM or when the clearing system, without such a request, generates a final settlement basis (Section 3.8.29). Other than as set forth in the R\&R regarding protests (Section 3.9), transfer orders may not be revoked after receipt of such settlement basis by NOMX DM.

Transfers of funds in SEK are made through the RIX system operated by the RB. With respect to transfers in Danish kronor, NOMX DM uses Denmark's central bank's payment system Konors. Both systems are designated payment systems under the Settlement Finality Directive. The settlement of Swedish financial instruments is made through Euroclear Sweden. With respect to transfers of Danish, Finnish and Norwegian financial instruments NOMX DM uses the Danish centralized securities depository (CSD)'s (VP Securities A/S) system, the Finnish CSD's (Euroclear Finland) system and the Norwegian CSD's (VPS) system. All systems used are designated securities settlement systems under the Settlement Finality Directive.

NOMX DM uses commercial banks as settlement agents for settlements in euro (SEB, Helsinki) and Norwegian kronor (SEB, Norway). All countries where settlement banks are engaged by NOMX DM have implemented the Settlement Finality Directive (see Recommendation 9 and 10 for more details).

\section{Enforceability oNSCC rules/procedures/contracts (Q3)}

Under the Bankruptcy Act financial instruments listed at a Swedish or foreign exchange authorized marketplace or any other regulated market can be realized immediately by the one that holds the instrument as collateral. Supplementary collateral, pledged for example due to market changes, are protected from revocation provided that the pledge, under the existing circumstances, can be considered as ordinary.

The R\&R give NOMX DM wide discretions in the event of a participant's default. For instance NOMX DM has a wide discretion with respect to the choices and options it is entitled to elect when a participant is deemed to be in default (see Recommendation 6 for more details).

\section{Cross-border activities (Q4)}

Based on the R\&R, NOMX DM's activities are governed by the laws of Sweden. However other jurisdictions can affect the relation between NOMX DM and its participants when it comes to third party rights, which comes from the fact that NOMX DM has several (24 in 2010) foreign members. 


\begin{tabular}{|c|c|}
\hline & $\begin{array}{l}\text { When a participant pledges collateral, potential third party rights to the collateral } \\
\text { have to be assessed according to the law in the country where the dematerialised } \\
\text { financial instrument is registered (Financial Instruments Trading Act, Chapter } 5 \\
\text { Section 3). Applicable laws with regard to third party rights to collateral might be } \\
\text { the laws in the country where the Custodian Institution is situated. Swedish law will } \\
\text { be applicable to the Custodian Institutions of NOMX DM that are situated in } \\
\text { Sweden. With regard to the active Custodian Institutions situated in Denmark, } \\
\text { Norway and Finland, it could be noted that these countries have implemented the } \\
\text { Finality Directive and the Collateral Directive and thus have similar protection for } \\
\text { the posted collateral as Sweden. } \\
\text { The conflict of law issues are solved by the Settlement Systems Act which states } \\
\text { that if a participant in a notified settlement system is in default, the rights and } \\
\text { obligations of that participant is governed by the law appointed by the system. This } \\
\text { means that Swedish law, since the R\&R appoint Swedish law as applicable, will be } \\
\text { applicable for the participants at NOMX DM in an insolvency situation. }\end{array}$ \\
\hline Assessment & Observed \\
\hline Comments & $\begin{array}{l}\text { The legal framework applying to NOMX DM is well-founded. FI's approval of } \\
\text { changes in the R\&R would provide further confidence in maintaining coherence } \\
\text { with the legal framework and consistency with the whole risk management } \\
\text { framework. }\end{array}$ \\
\hline Recommendation 2. & $\begin{array}{l}\text { A CCP should require participants to have sufficient financial resources and robust } \\
\text { operational capacity to meet obligations arising from participation in the CCP. A } \\
\text { CCP should have procedures in place to monitor that participation requirements are } \\
\text { met on an ongoing basis. A CCP's participation requirements should be objective, } \\
\text { publicly disclosed, and permit fair and open access. }\end{array}$ \\
\hline Description & $\begin{array}{l}\text { Sufficient financial resources and robust operational reliability (Q1) } \\
\text { NOMX DM offers two types of clearing: member clearing and customer clearing. } \\
\text { There are two types of member clearing: } \\
\text { - A General Clearing member (GCM) is entitled to participate in the clearing } \\
\text { activities of the clearing house on its own behalf, on behalf of customers, on } \\
\text { behalf of Non-Clearing Members (NCM), the latter ones being trading members } \\
\text { which are not clearing members. } \\
\text { - A Direct Clearing Member (DCM) is entitled to clear on its own behalf and on } \\
\text { behalf of customers. } \\
\text { A clearing member may provide two customer clearing models and possibly a } \\
\text { combination of two: } \\
\text { - The principal to principal model: in such a case, NOMX DM does not have any } \\
\text { legal relationship with members' customers; customers and NCMs have } \\
\text { counterparty risk against the clearing member; the clearing member is fully } \\
\text { liable towards NOMX DM for customer and NCM contracts. } \\
\text { The agent customer clearing model: the member act as agent, i.e., represents the } \\
\text { customer in all respects towards NOMX and is liable (with limitations and } \\
\text { jointly with the customer) for customer's contracts; customers have a direct } \\
\text { legal relationship with NOMX DM and customers have rights and obligations } \\
\text { under the R\&R; customers are margined separately on customer level and there }\end{array}$ \\
\hline
\end{tabular}


is no position netting between customers (margins are required gross per customer) or between members and customers. The customers may be either an indirect pledging customer or a direct pledging customer. In this latter case, customers have no counterparty risk towards the agent clearing member in case of clearing member default. The risk is against NOMX DM and to a certain extent against the Custodian Institution holding the collateral the customer has pledged in favor of NOMX DM. NOMX DM has currently about 500 such direct pledging customers.

Participation criteria to NOMX DM are defined in Section 3.2 of the R\&R and apply to GCM and DCM. Customers under the agent customer clearing model are not subject to specific requirements.

GCM and DCM must be allowed to operate securities business in accordance with the law of the country where they are domiciled.

The minimum capital requirement is SEK 500 million for GCM and SEK 10 million for DCM for all the products cleared.

To assess the creditworthiness of an applicant, the Risk Management Department (RMD) reviews information regarding financial stability, historical financial performance, ownership, affiliated companies and debt ratings before making the decision whether to approve the applicant or not. The same factors are considered and monitored for all already approved members to ensure ongoing creditworthiness.

The R\&R also stipulate that members must have suitable banking arrangements, organization, necessary risk management routines, sound information technology (IT) systems and otherwise be suitable in NOMX DM's opinion to participate in clearing operations. Each member should have at least one designated contact person responsible for clearing and settlement issues and have at least two employees who fulfill the requirements applicable to back office personnel. There are specific education and knowledge requirements for member staff, for which NOMX DM provide training.

Operational capability is assessed when the member is applying for a membership. Ongoing monitoring of the members' operational capacity of the members is done by collecting data and information from different sources, e.g., NOMX DM operations, surveillance, RMD and the members.

\section{Monitor compliance with participation requirements $(\mathbf{Q} 2)$}

Members are monitored by Risk Management and Operations Departments, with support from Legal Department in order to ensure that the membership requirements are at all times fulfilled.

The RMD reviews all members minimum once per year. There are two full-time positions within the RMD dedicated to monitoring the counterparties of NOMX DM.

To assess the creditworthiness of a member, the RMD reviews information regarding financial stability, historical financial performance, ownership, affiliated companies and debt ratings. The financial information is used to assure compliance with the minimum financial requirements for membership, establishment of internal risk ranking and various risk limits per member. Financial highlights are also tracked for each member to identify major changes affecting the creditworthiness of 
each member.

If a specific counterparty is considered to be above average risk regarding its creditworthiness, there is a special Credit Watch routine in place in order to monitor and follow-up that counterparty on a more frequent basis than normal standard. It involves additional credit assessments and reporting to predefined functions and staff within the organization. If information publicly available is not deemed sufficient to make a fair credit assessment, the counterparty is contacted and asked to supply NOMX DM with supplemental information.

\section{Suspension and termination of participants' membership}

The R\&R specify clearly the circumstances in which NOMX DM may suspend or terminate the membership of a member. Section 1.9.1 of the R\&R defines these circumstances: if the member is in breach of the R\&R or if in the opinion of NOMX there is a substantial risk that the member will be in breach of the $R \& R$, or the member is no longer suitable to be a member pursuant to the $R \& R$ or the Swedish Securities Market act, for instance as a result of bankruptcy or existence of circumstances which objectively indicate that the member is insolvent or will soon become insolvent. NOMX is thereupon entitled to take measures in accordance with what is set forth in section 1.9.12 of the R\&R. This includes the right to refuse exchange transactions and registration.

Matters concerning default in the clearing operations are decided by the Clearing Default Committee.

Under Section 1.15.1 of the R\&R, where circumstances occur which are outside NOMX's control and which seriously affect its possibilities to maintain properlyfunctioning exchange and clearing operations, NOMX has the right to adopt such measures as it deems fit to ensure such aim. Such measures include the right to cease or limit exchange or clearing operations.

NOMX DM has the possibility to suspend a participant from trading and clearing activities in one of NOMX DM's internal systems. The suspension can be effectuated immediately and all orders belonging to the participant would be inactivated.

During a suspension or in case of termination of membership, NOMX may, to cater for an orderly wind down of contracts, accept requests by the suspended member to enter into new transactions/close-out Transactions. Such transactions would be subject to NOMX' approval and would normally be carried out via NOMX' manual order book.

In default situations NOMX DM has established a close co-operation with the defaulting counterparty to find an efficient and orderly way of managing/closing-out the market risk in the counterparty's portfolio. Customers' contracts with the defaulting member have to a large extent been re-registered with other clearing members in connection with the default of a clearing member. In this respect the member has an obligation under the R\&R, following demand by NOMX, to take all measures necessary in order to transfer Customers' contracts to other members and to transfer any collateral pledged by the end customer to the member. A corresponding obligation applies in relation to contracts registered or recorded on segregated accounts on behalf of customers or NCMs. 


\begin{tabular}{|c|c|}
\hline & $\begin{array}{l}\text { Open and fair access (Q3) } \\
\text { The same rules apply to all applicants and the standards. The participation } \\
\text { requirements are clearly stated and publicly disclosed in the R\&R. The rules in the } \\
\text { R\&R covering default are also publicly disclosed. }\end{array}$ \\
\hline Assessment & Broadly Observed \\
\hline Comments & $\begin{array}{l}\text { NOMX DM has established adequate membership requirements. However, direct } \\
\text { pledge end customers, that have direct relationships with NOMX DM, are not } \\
\text { subject to specific requirements though NOMX DM has direct counterparty risk } \\
\text { with them. NOMX DM should set participation requirements for direct pledge end } \\
\text { customers. It should be noted that NOMX DM has started a process for possibly } \\
\text { setting requirements for such end customers. }\end{array}$ \\
\hline Recommendation 3. & $\begin{array}{l}\text { A CCP should measure its credit exposures to its participants at least once a day. } \\
\text { Through margin requirements, other risk control mechanisms or a combination of } \\
\text { both, a CCP should limit its exposures to potential losses from defaults of its } \\
\text { participants in normal market conditions so that the operation of the CCP would not } \\
\text { be disrupted and non-defaulting participants would not be exposed to losses that } \\
\text { they cannot anticipate or control. }\end{array}$ \\
\hline Description & $\begin{array}{l}\text { Measurement of exposures (Q1) } \\
\text { NOMX DM calculates margins on an end-of-day and intra-day basis for members } \\
\text { and direct pledge customers. The end-of-day calculation is used to determine the } \\
\text { amount of collateral to be pledged to the Custodian Institution (see } \\
\text { Recommendation } 7 \text { for the definition). Risk exposures are also measured hourly } \\
\text { from 10:00 a.m. through to 6:00 p.m. via automatic intra-day risk reporting. } \\
\text { The official margin requirement calculated end of day has to be met by } 11.00 \text { a.m. } \\
\text { the day after. } \\
\text { The intra-day calculations are based on real-time positions, i.e., a full reevaluation is } \\
\text { always done. The equity products are evaluated with real-time prices. The fixed } \\
\text { income derivatives products are evaluated with last traded derivatives price, while } \\
\text { NOMX DM has the capacity to source and use real-time prices from primary dealers } \\
\text { if needed, i.e., in default situations. } \\
\text { It must be noted that a margin simulation facility is also open to members and } \\
\text { provides them with the capacity to simulate the margin requirements at any time and } \\
\text { also to alter the positions in their portfolio in order to simulate the effect on the } \\
\text { margin requirements. } \\
\text { Risk mitigation tools (Q2) } \\
\text { Exposure to potential counterparty default is limited by NOMX DM having a risk } \\
\text { management framework based on conservative margin requirements, an intraday } \\
\text { risk policy, and concentration limits. } \\
\text { Margin requirements: NOMX DM relies on portfolio-based margining systems that } \\
\text { are used to calculate the amount of collateral to compensate for the counterparty risk } \\
\text { it assumes in its capacity as a clearing house. The validity of the margining } \\
\text { methodology has been supported by regular back testing (see Recommendation } 5 \text { ). } \\
\text { Intraday risk policy: An intraday risk policy, decided by the Clearing Risk } \\
\text { Committee, was introduced on September } 25,2009 \text { and has not been changed since }\end{array}$ \\
\hline
\end{tabular}




\begin{tabular}{|c|c|}
\hline & $\begin{array}{l}\text { then. This policy requests NOMX DM to call for additional margin intraday in case } \\
\text { the real-time margin requirement for a counterparty increases with more than SEK } \\
200 \text { million during the day. The size of the limit is partly connected to the overall } \\
\text { clearing capital and the level of acceptable overnight risk. The intraday exposure } \\
\text { limit is decided by NOMX STO board of directors. In addition to this intraday risk } \\
\text { policy, a system of limits linked to an internal risk ranking of participants has been } \\
\text { set up in order to monitor more closely members whose margin requirements would } \\
\text { become unusually higher than what they are on average. Such monitoring is ensured } \\
\text { by the RMD. } \\
\text { Concentration limits: NASDAQ OMX DM applies concentration limits in terms of } \\
\text { positions. For fixed income the concentration limit is set to } 25 \text { percent of the } \\
\text { outstanding volumes and for equities the limit is set to } 10 \text { percent of outstanding } \\
\text { volumes. These concentration limits are decided by the Clearing Risk Committee } \\
\text { (see Recommendation 13). } \\
\text { It must be highlighted that the structure used by NOMX DM does not enforce a loss- } \\
\text { sharing scheme with the clearing members. Instead NOMX assumes the full } \\
\text { counterparty risk in default situations. }\end{array}$ \\
\hline Assessment & Observed \\
\hline Comments & \\
\hline Recommendation 4. & $\begin{array}{l}\text { If a CCP relies on margin requirements to limit its credit exposures to participants, } \\
\text { those requirements should be sufficient to cover potential exposures in normal } \\
\text { market conditions. The models and parameters used in setting margin requirements } \\
\text { should be risk-based and reviewed regularly. }\end{array}$ \\
\hline Description & $\begin{array}{l}\text { Models and parameters to set margins (Q1) } \\
\text { NOMX DM requires margins for all cleared products. For equity and fixed income } \\
\text { derivatives, NOMX DM uses a scenario based margin methodology called OMS II, } \\
\text { built in house and introduced in 2003, and for repos a yield curve based model } \\
\text { called Cash Flow Margin (CFM), implemented in } 2010 \text { when repo clearing started. } \\
\text { Parameters used to determine the margin levels } \\
\text { The margin requirements are intended to cover NOMX DM in the case of } \\
\text { counterparty defaults during adverse but not extreme market conditions. The } \\
\text { margins are set to cover the expected time to liquidate positions in case of a member } \\
\text { default. For equity products and fixed income forward and options, two days are } \\
\text { applied. For less liquid products, a higher time span is set: } 3 \text { lead days for the SEK } \\
\text { repo.. The time interval is based upon the Risk Committee's view of how long it } \\
\text { would take to close out the exposure in a portfolio for the specific products. } \\
\text { The price estimations (i.e., volatility for equity and fixed income, shift in curve for } \\
\text { repo and swaps) are based on one-year historical data for each underlying } \\
\text { instrument. For instance, for volatility, it is the second largest volatility in absolute } \\
\text { terms experienced during last } 12 \text { months. The Risk Committee may add a forward } \\
\text { looking view by having an opinion on the current and future market volatility which } \\
\text { can lead to a decision to have more conservative parameters than the calculated } \\
\text { ones. The Risk Committee reviews the risk parameters on a quarterly basis. } \\
\text { The margin parameters are calculated with a numerical statistical method using a } \\
99.2 \text { percent confidence interval. }\end{array}$ \\
\hline
\end{tabular}




\section{Validation of the models}

The models and the parameters are reviewed and approved by the Clearing Risk Committee, and have been reviewed by NOMX Internal Audit with the help of an external consultant.

Any material change to the margining methodology requires specific internal approval by the Clearing Committee and FI is informed. No significant changes to the OMS II margin methodology has been made since it was implemented in 2003. The new CFM model was approved by the Risk Committee and has been reviewed by Internal Audit via external consultants.

The RMD implements back-testing on a daily basis. Margin back-testing results have so far validated the adequacy of NOMX DM's margining requirements. The assumption has also been proven reasonable based on actual defaults successfully managed by NOMX DM.

If NOMX DM's margining validation tests were to generate results that raised questions or doubts about the adequacy of margining requirements, the RMD is required to address the issue with NOMX DM's Clearing Risk Committee.

\section{Intraday margin calls $(\mathbf{Q} 2)$}

NOMX DM's policy is to calculate and require intraday margin as a means of maintaining a desired margin coverage. It can make intraday margin calls at anytime it chooses to do so. The Intraday Risk Policy is to always call for additional margin intraday in case the real-time margin requirement for a counterparty increases with more than SEK 200 million during the day.

\section{Assets accepted as margins and related haircuts (Q3)}

The list of assets accepted as margins is set in a Collateral List, as an Appendix 12 to the R\&R, which is regularly updated. Eligible assets are the following:

- Cash in various currencies

- Bank guarantees (subject to criteria and specific approval),

- Government bonds and bills (for selected countries and subject to minimum debt rating restrictions),

- Commercial paper (for selected issuers and subject to minimum debt ratings),

- Bonds issued by banks or financial institutions (for selected issuers and subject to minimum debt ratings),

- Certificates of deposits (for selected banks in selected countries and subject to minimum debt ratings), and

- Stocks (for selected issuers listed on the NASDAQ OMX Nordic List, all of which are subject to a range of limitations tied to liquidity and concentration risk management control issues).

Custodian Institutions manage collateral on behalf of NOMX DM, and confirm at minimum once per business day, at 12 am at the latest, to NOMX DM if sufficient collateral has been pledged by the clearing participants. It is the responsibility of the Custodian Institutions to ensure that all collateral that is held complies with the collateral eligibility requirements and is valued based on the haircuts which are stipulated in the R\&R (see Recommendation 7 for further details).

NOMX DM may at any time require the exact details of the pledged assets from the Custodian Institutions. A full scale inquiry to all Custodian Institutions covering all 
clearing participants is usually done by N OMX DM once per year.

The most recent inquiry was made in May 2010, and at that time the asset class breakdown was: 33 percent government securities, 28 percent in bank/mortgage institution securities, 24 percent cash, 10 percent guarantee, 5 percent large cap equities and 0 percent mid cap equities.

NOMX DM holds directly the bank guarantees, the details of such collateral being monitored and controlled by the RMD. Six counterparties currently pledge guarantees.. These guarantees are provided by the major Swedish banks that are also CCP members. The value of the six existing bank guarantees is 3,043 bio SEK in total.

Under the R\&R and the Custodian Institution Agreements, the assets are revaluated at least once every bank day. With regard to the sections in the R\&R that apply to eligible collateral, it is the risk management function's responsibility to ensure that these are at all times appropriate.

Haircuts are applied according to a collateral value list. They are designed to ensure that the net liquidation value of the assets is equal to or exceeds the margin required between the last valuation and liquidation. The haircuts are revaluated semi-annually and any potential change in asset value or volatility affects the haircuts.

Haircuts are the following ones:

- Government Treasury Bills and bonds :

\begin{tabular}{|l|l|l|l|}
\hline $\begin{array}{l}\text { Maturity } \\
\text { (Year) }\end{array}$ & Haircut & $\begin{array}{l}\text { Maximum } \\
\text { Amount }\end{array}$ & Minimum Debt Rating \\
\hline $0-5$ & $95 \%$ & None & S\&P: AA+\& Moody's: Aa1 \\
\hline $5-10$ & $93 \%$ & None & S\&P: AA+\& Moody's: Aa1 \\
\hline$>10$ & $90 \%$ & None & S\&P: AA+\& Moody's: Aa1 \\
\hline
\end{tabular}

Maximum amount limit is NOK 300 million on Norwegian Government Treasury Bills and Bonds.

- Bonds issued by banks or mortgage-credit institutions (Denmark) and issuing institutions (Sweden) :

\begin{tabular}{|c|c|c|c|}
\hline $\begin{array}{l}\text { Maturity } \\
\text { (Year) }\end{array}$ & Haircut & Maximum Amount & Minimum Debt Rating \\
\hline $0-5$ & $90 \%$ & \multirow{3}{*}{$\begin{array}{l}\text { DKK } 800 \text { / SEK } \\
1000 \text { / } 850 \text { NOK / } \\
100 \text { EUR / } 140 \text { USD / } \\
90 \text { GBP million per } \\
\text { issuer }\end{array}$} & S\&P: A- or Moody's A1 \\
\hline $5-10$ & $85 \%$ & & S\&P: A- or Moody's A1 \\
\hline$>10$ & $80 \%$ & & S\&P: A- or Moody's A1 \\
\hline
\end{tabular}

Note: 20 percent haircut and maximum amounts EUR 37.5 million per issuer on Bonds issued by Finnish deposit banks and mortgage credit banks.

Haircuts for equities are in the range of 70 percent - 50 percent depending of the 


\begin{tabular}{|c|c|}
\hline & $\begin{array}{l}\text { segment (large cap/mid cap) and the average value traded on the market. In addition, } \\
\text { there is a concentration limit on the maximum value of one specific stock that may } \\
\text { be remitted as collateral. }\end{array}$ \\
\hline Assessment & Broadly Observed \\
\hline Comments & $\begin{array}{l}\text { The margin requirements set by NOMX DM cover its potential exposures to its } \\
\text { clearing members' positions in normal market conditions. NOMX DM bases the } \\
\text { models and the parameters used in determining margin requirements on the risk } \\
\text { characteristics of the products cleared. NOMX DM regularly validates coverage of } \\
\text { the models and parameters. NOMX DM has the capacity to make intraday margin } \\
\text { calls. } \\
\text { NOMX DM accepts as collateral to meet margin requirements bank guarantees } \\
\text { which by definition are not liquid resources. In addition, these bank guarantees are } \\
\text { provided by banks which are also NOMX DM's members, while two of them are the } \\
\text { sole liquidity providers. In addition there is a risk of sectorial concentration of the } \\
\text { collected collateral: for instance banks may represent about } 30 \text { percent of collected } \\
\text { collateral on a specific day. NOMX DM should not accept bank guarantee as } \\
\text { collateral due to the fact that such collateral is not liquid and that providers of such } \\
\text { guarantees are NOMX DM's members. }\end{array}$ \\
\hline Recommendation 5. & $\begin{array}{l}\text { A CCP should maintain sufficient financial resources to withstand, at a minimum, a } \\
\text { default by the participant to which it has the largest exposure in extreme but } \\
\text { plausible market conditions. }\end{array}$ \\
\hline Description & $\begin{array}{l}\text { Stress testing (Q1) } \\
\text { NOMX DM has developed a stress test methodology (RCaR / RIVA Capital at Risk) } \\
\text { to estimate how much financial resources it needs in addition to the required } \\
\text { margins to cover its losses in extreme conditions in case of default of the two } \\
\text { members having the largest exposures. The methodology is based on the model used } \\
\text { to calculate the margin requirements with the risk parameters being stressed. } \\
\text { It must be stressed that the methodology is applied both to NOMX DM and NOMX } \\
\text { COM, the Norwegian CCP. In practice the calculation is applied separately for both } \\
\text { clearing houses and the two largest exposures for both CCPs are summed up, which } \\
\text { results in the estimated needed financial resources. } \\
\text { Cleared instruments are grouped into stress tested markets per asset class and } \\
\text { instrument country. Two market scenarios are evaluated within each stress tested } \\
\text { market: the market price of instruments is stressed up and the market price of } \\
\text { instruments is stressed down, with the correlation between the instruments set to } 1 \text {. } \\
\text { The correlation between the different stress tested markets is set to } 0 \text { which results in } \\
\text { a total of } 2 \text { to the power of scenarios evaluated. The stressed market move for } \\
\text { individual instruments within a stress test market is }+/-150 \text { percent of the margin } \\
\text { risk interval parameter for non-index instruments and }+/-200 \text { percent for index } \\
\text { instruments. } \\
\text { The scenarios currently used in RCaR calculations for NOMX DM are compared } \\
\text { with historical scenarios. The stressed market movements are well over the most } \\
\text { volatile periods that have been experienced by NOMX DM. The current stress test } \\
\text { parameter for OMXS30 Index is } 14 \text { percent compared to the largest one and two-day } \\
\text { movement in the Index since Jan } 2008 \text {, an extreme volatile period, which is an } \\
\text { upward movement of } 12.6 \text { percent. }\end{array}$ \\
\hline
\end{tabular}


In addition to the capital held to cover the two largest exposures, NOMX DM holds capital equal to the sum of all remaining clearing participants' risk weighted exposures (measured as probability of default * stress exposure in the same stress scenario) as well as a buffer to cover the model risk.

This stress testing is regularly and frequently conducted:

- on a daily basis, a stress test is performed, separately for NOMX DM and NOMX COM (excluding the evaluation of the risk-weighted exposures of all clearing participants).

- on a quarterly basis, a stress test including the evaluation of the risk-weighted exposures of all clearing participants is performed for the combination of all clearing participants and all cleared instruments in both CCPs

- on an annual basis, a comprehensive review of models, parameters and scenarios is conducted. Parameters are reviewed quarterly at the same time as the normal margin parameter review.

- the stress test model and scenarios are reviewed by the Regulatory Capital Committee on a quarterly basis and more comprehensively on an annual basis.

\section{Sufficiency of resources to cover losses}

Based on the results provided by the stress testing, the actions to be taken according to the policy include a change of clearing capital to meet the capital requirement implied by the stress test calculations or a reduction of risk exposure.

Based on the policy, decision to change the composition of the regulatory capital has to be proposed by the Regulatory Capital Committee. Members of the Regulatory Capital Committee are:

- President of NOMX STO as the Chair

- Group Treasurer

- Local Risk Management Heads

- U.S. Global Treasury (Head of Risk Capital Strategy \& Management for NOMX Group)

- $\quad$ Head of Legal NOMX STO.

The Regulatory Capital Committee is vested with the authority to determine and implement all changes necessary to fulfill all regulatory requirements. The decision taken in the Regulatory Capital Committee should be documented, describing the reasoning behind the decision if the capital should be adjusted or not. Minutes shall be taken by the Head of RMD and approved by Head of the Legal Department. Decisions are taken by the President of NOMX STO, in agreement with the Group Treasurer. If no agreement is reached the decision will be escalated to the NOMX STO and NASDAQ OMX Nordic Exchange Group Limited's Board of Directors. NOMX STO and NASDAQ OMX Nordic Exchange Group Limited's Board of Directors and the regulatory authorities should be informed about any decisions and changes.

\section{Ability to draw on financial resources (Q2)}

Based on the stress testing, an amount of financial resources (called the regulatory capital) specifically dedicated to clearing activities has been defined and set at SEK 2,270 million. This regulatory capital consists of Clearing Capital (SEK 1,970 million) and Operational Capital (SEK 300 million). The Clearing Capital is the buffer capital to be used in the event of a counterparty default where the collateral is 
insufficient. The Operational Capital is a buffer capital to assure persistent business and/or orderly wind down and to cover operational losses.

The operational capital corresponds to the resources deemed needed to run the CCP for 1 to 2 quarters, with the objective that this period would be appropriate to orderly winding down the operations. The current calculation was provided to FI in connection with the merger with NOMX Oslo in end 2009. This part of the capital was then raised from SEK 150 to 300 million.

It must be stressed that the regulatory capital covers both CCP,; NOMX DM and NOMX COM, and that it does not include a mutualised default fund.

The regulatory capital is composed of:

- own capital resources of SEK 720 million, made of SEK 251 million in share capital and restricted reserves and 469 MSEK in retained earnings.

- SEK 1,550 million represented by an insurance policy provided by OMX Capital Insurance AG (OMXCI).

OMXCI, authorized by the Swiss insurance regulator, is a wholly-owned insurance company within the NASDAQ OMX Group. OMXCI has no other insurance undertakings than the policy with NOMX DM. OMXCI has own financial resources of 750 MSEK invested in low risk government securities and dedicated to the clearing capital. These assets are fully financed by shareholder's equity. In addition, OMXCI benefits a financial guarantee of 800 MSEK which can be drawn in the event of counterparty defaults. This guarantee is issued by SEB (which is a NOMX DM's member) and is collateralized with government bonds, the latter being held with Danske Bank (which is also a member) under an escrow account.

In case the regulatory capital would not be sufficient to cover the losses, NOMX STO capital can be used to cover losses in excess of the size of the regulatory capital. Currently, NOMX STO has a total shareholders' equity of SEK 3,788 MSEK (as per Dec 31 2009). Of this amount, 941 MSEK is non regulatory tangible capital, in excess of the regulatory capital, which could be utilized to absorb losses.

The resources are used in the order described in the illustrative graph below, starting from the left:

NOMX STO's own assets in the Clearing Capital are held in an escrow account arrangement with Danske Bank as a third party and completely ring-fenced from other liquidity needs in NASDAQ OMX Group. Any funds can only be transferred from the escrow accounts in the event of counterparty default in NOMX STO clearing activities or in case of increase in value.

\section{Immediate availability of financial resources $(\mathrm{Q} 3)$}

All financial resources dedicated to the Clearing Capital should in theory be immediately available. The part of the regulatory capital made of own resources (720 MSEK) is invested:

- In low risk Swedish government securities up to 420 MSEK (the part of the Clearing Capital); and

- In NASDAQ OMX's cash pool (the Operational Capital), which is managed by the Group Treasury.

In addition to these own resources and OMXCI guarantee, NOMX DM has 


\begin{tabular}{|c|c|}
\hline & $\begin{array}{l}\text { committed and unsecured credit line arrangements of around 1,300 MSEK with two } \\
\text { Swedish banks, SEB and Danske Bank, which can be utilized with same day value. } \\
\text { In the event of a default by a member, the R\&R stipulate that NOMX DM is entitled } \\
\text { to immediately have recourse to the collateral provided by the defaulting member. } \\
\text { It can be observed that, based on RB rules, it is legally possible for NOMX DM as a } \\
\text { clearing organization to have access to intraday credit with RB, as well as the } \\
\text { deposit facility. However NOMX DM has so far not requested the RB to implement } \\
\text { these possibilities. }\end{array}$ \\
\hline Assessment & Partly Observed \\
\hline Comments & 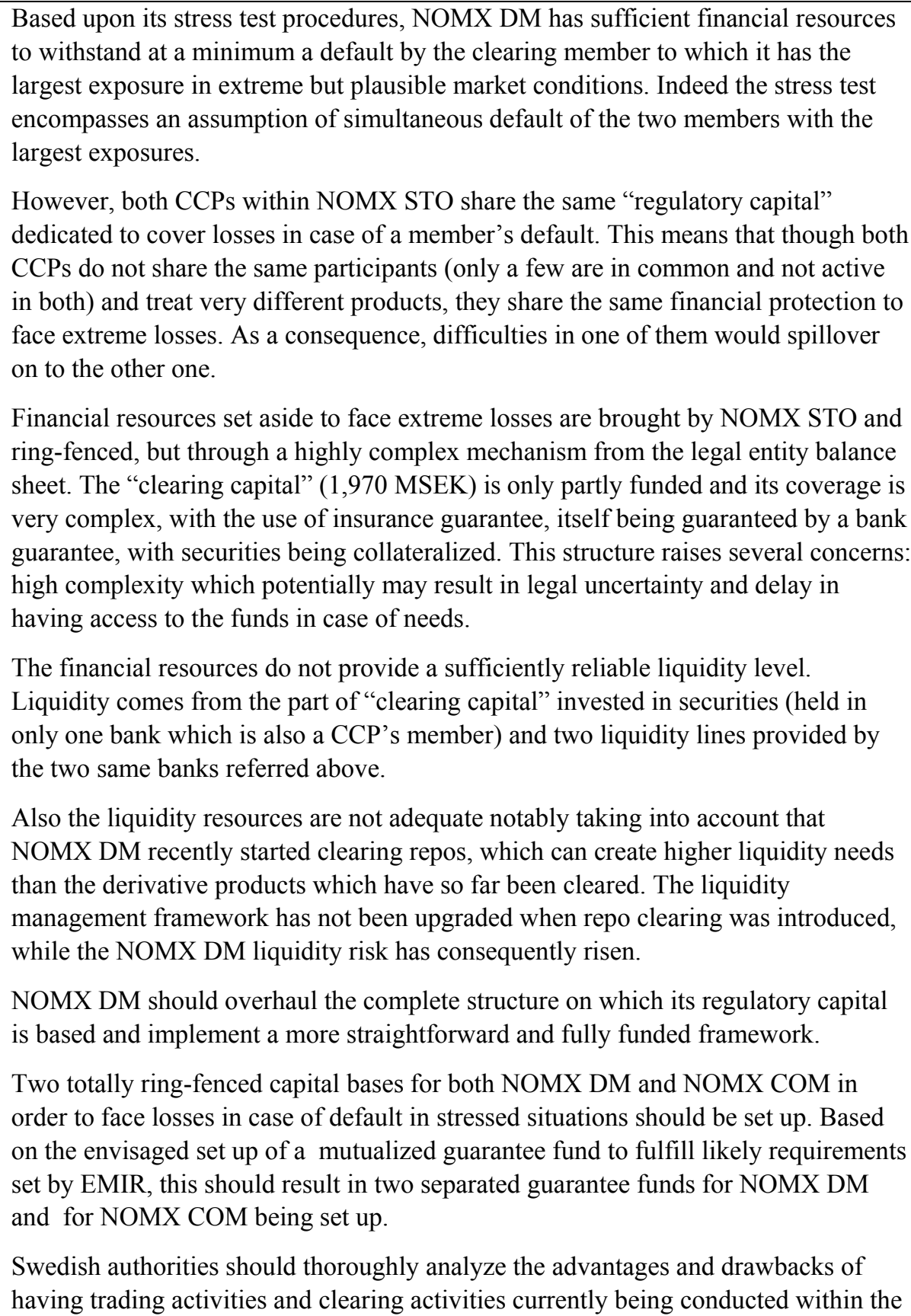 \\
\hline
\end{tabular}




\begin{tabular}{|c|c|}
\hline & $\begin{array}{l}\text { same legal entity, NOMX STO. For sake of clarity, clearing activities could be } \\
\text { isolated in a distinct legal entity. } \\
\text { NOMX DM should enhance its liquidity framework. It should ensure that the } \\
\text { collateral collected present a high degree of liquidity and consequently bank } \\
\text { guarantees should be excluded. NOMX DM should raise the number of its liquidity } \\
\text { providers (only two currently). NOMX DM should put in place the operational set } \\
\text { up so that it can use, in case of needs, the intraday liquidity that may be provided by } \\
\text { RB. Also it would be of interest for NOMX DM to operationally implement the } \\
\text { deposit facility that it can be provided with by RB, so that in case of need (distressed } \\
\text { market) that possibility could be immediately used. } \\
\text { It has to be noted that NOMX DM is contemplating to put in place a new Collateral } \\
\text { Management Service (see recommendation 7) which would result in several } \\
\text { enhancements to the current set up. Notably NOMX DM would then be in a position } \\
\text { to access the cash deposited as collateral and to invest that cash collateral in liquid } \\
\text { assets that, in case of need, may then be repoed with the central bank to obtain } \\
\text { intraday liquidity. }\end{array}$ \\
\hline Recommendation 6. & $\begin{array}{l}\text { A CCP's default procedures should be clearly stated, and they should ensure that the } \\
\text { CCP can take timely action to contain losses and liquidity pressure and to continue } \\
\text { meeting its obligations. Key aspects of the default procedures should be publicly } \\
\text { available. }\end{array}$ \\
\hline Description & $\begin{array}{l}\text { Definition of default and clarity of default procedures (Q1) } \\
\text { The R\&R (sections } 1.9 .1,1.9 .2 \text { and 1.9.3) clearly state what constitutes a default and } \\
\text { give wide discretions in the event of a participant's default. The default procedures } \\
\text { provide NOMX DM with the authority to promptly close out or manage the } \\
\text { positions of a defaulting participant The default procedures (Section } 1.9 .12 \text { (viii) of } \\
\text { the R\&R) permit the transfer as well as the liquidation of the positions and the } \\
\text { collateral of customers of the defaulting participant. As far as possible NOMX DM } \\
\text { shall protect the customers from damage and should in first instance try to re- } \\
\text { register the customer contracts with another clearing participant of good standing. } \\
\text { NOMX DM has the ability to immediately seize and use a defaulting participant's } \\
\text { collateral. } \\
\text { NOMX DM's policy with regard to ensuring the timely resolution of large and } \\
\text { complex portfolios is to contract, if possible and appropriate, a minimum of two } \\
\text { independent banks to quote prices on instruments in order to facilitate the unwinding } \\
\text { of positions. Whenever NOMX DM considers entering a new market or launching a } \\
\text { new product this policy has to be observed. In addition, NOMX DM has its own } \\
\text { broker desk which is required to support in the resolution of portfolios in a default } \\
\text { scenario. } \\
\text { The default process is designed differently depending on the market structure. In the } \\
\text { equity derivatives markets, NOMX DM will utilitize its internal broker desk to close } \\
\text { out the porfolio via the electronic orderbook or via OTC negotiated trades. For the } \\
\text { fixed income OTC products banks are contracted to quote prices in case of a default } \\
\text { situation. For the repo market, } 4 \text { banks have signed an agreement to quote prices in } \\
\text { case of a default. } \\
\text { During a suspension or in case of termination of membership, NOMX DM may } \\
\text { accept requests by the suspended member to enter into new transactions/close-out }\end{array}$ \\
\hline
\end{tabular}


transactions in order to achieve an orderly wind down.

In the few default situations that have occurred (notably one recent default in 2010), NOMX DM has established a close co-operation with the defaulting counterparty to find an efficient and orderly way of managing/closing-out the market risk in the counterparty's portfolio. Customers' contracts with the defaulting member have to a large extent been re-registered with other clearing members. In this respect the member has an obligation under the R\&R, following demand by NOMX DM, to take all measures necessary in order to transfer Customers' contracts to other members and to transfer any collateral pledged by the end customer to the member. A corresponding obligation applies in relation to contracts registered or recorded on segregated accounts on behalf of customers or NCMs.

It should be noted that the structure of segregation under the agent clearing model highly facilitates the transfer of collateral and positions of end-customers in case of a member's default (see Recommendation 2 for more details).

\section{(Legal) enforceability of default procedures (Q2)}

The R\&R provide a high degree of assurance that NOMX DM's decisions in matters which are directly associated with default events and default handling would not be stayed or reversed (see Recommendation 1).

\section{Internal plans for managing defaults $(\mathrm{Q3})$}

The default management procedures, as well as the underlying clearing and risk model, are designed to minimize the market impact of a default while still ensuring the stability of NOMX DM.

In case of a member's default, a Clearing Default Committee is in charge of managing the default using the above-mentioned alternative actions. It consists of the following representatives, which are specifically selected to provide for informed decisions in the interest of NOMX DM, NOMX DM's members including their customers, and the market:

- President of NOMX STO - as Chairman and with power of veto;

- Head of NOMX Clearing Risk Management Europe-Power of veto;

- Head of NOMX Clearing Risk Management Commodities;

- Head of NOMX Clearing Risk Management Financial Derivatives

- Head of NOMX Clearing Operations;

- Chief Legal Counsel NOMX STO (or alternate legal representative if unavailable);

- NOMX Treasurer Non-U.S.; and

- Any other person(s) deemed appropriate by the Clearing Default Committee during a default situation.

NOMX DM Clearing Default Committee's procedures are reviewed regularly (i.e., minimum annually). The RMD has the responsibility for ensuring that plans and procedures are maintained as current.

The plan is tested annually, unless actual defaults provide for real life validation of the default management procedures. The test is conducted as a fire drill covering one or several aspects of a default that has occurred historically or a hypothetical default, and typically involves several different departments within NOMX DM. The RMD is responsible for initiating, planning and executing the tests, as well as for reporting 


\begin{tabular}{|c|c|}
\hline & $\begin{array}{l}\text { the test results to management if necessary. } \\
\text { Transparency / publicity of default procedures (Q4) } \\
\text { The default procedures are publicly available on NOMX DM's web site as well as a } \\
\text { Default Management brochure providing for the key aspects of a default handling. }\end{array}$ \\
\hline Assessment & Observed \\
\hline Comments & \\
\hline Recommendation 7. & $\begin{array}{l}\text { A CCP should hold assets in a manner whereby risk of loss or of delay in its access } \\
\text { to them is minimized. Assets invested by a CCP should be held in instruments with } \\
\text { minimal credit, market and liquidity risks. }\end{array}$ \\
\hline Description & 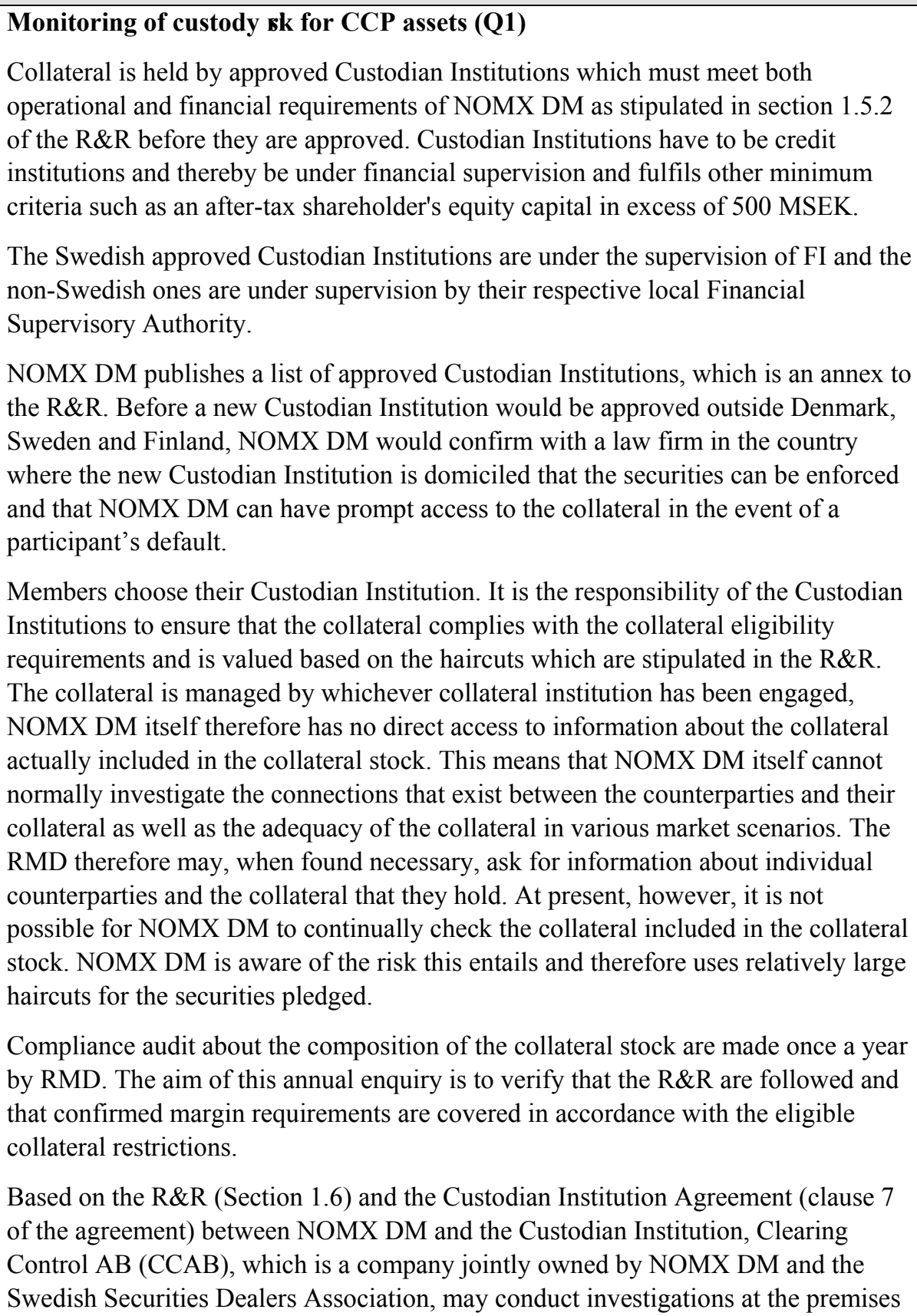 \\
\hline
\end{tabular}


of the Custodian Institution in order to investigate and confirm that sufficient collateral has been pledged. CCAB's task is to ensure that the customer contracts are correct and to carry out annual random tests to check that the collateral provided is acceptable and correct

Under the R\&R (Section 3.7.20) and the Custodian Institution Agreements (Section 4 ), the assets are revaluated at least once every bank day. The Custodian Institutions shall no later than 12.00 each bank day, inform NOMX DM whether the pledged collateral satisfies the applicable collateral requirements. NOMX DM is entitled to request that the Custodian Institutions revalue collateral in connection with NOMX DM's right to issue intraday margin calls.

All bank guarantees in favor of NOMX DM are held directly by NOMX DM.

NOMX DM does not evaluate the approved Custodian Institutions against the ESCB-CESR Recommendations for Securities Clearing and Settlement in the European Union.

\section{Investments of $\mathrm{CCP}$ resources $(\mathrm{Q} 2)$}

The NOMX Group's investment policy is primarily defined by Group Treasury and approved by NOMX Group's Finance Committee and Audit Committee. In addition to this, NOMX STO also has an own Regulatory Capital Policy which stipulates investment limits. The latter policy is approved by the Board of NOMX STO. Both polices should be fulfilled when investing clearing capital and excess cash.

Overall the policy stipulates that all Clearing Capital should be invested in Government Bills or Bonds with a maximum term of 30 years, or Mortgage Bills and Bonds with maximum term of 5 years (issued by an entity which does not belong to a group which is a member of the Clearinghouse). Maximum 40 percent of the portfolio could be invested in Mortgage Bonds or Bills. Lowest acceptable rating is A/A2. However, in practice NOMX STO has been investing in Swedish Government Bills and Bonds for the last 10 years (AAA rated) and a benchmark for the portfolio has been defined consisting of solely Swedish Government Bills and Bonds with an average duration of approximately 2.5 years. Any substantial shift in investments would be brought up in the Regulatory Capital Committee.

Bank guarantees accepted as collateral for derivatives are subject to several requirements such as a minimum $\mathrm{A}$ - rating.

OMX Treasury AB, which functions as the group's internal bank in a separate legal entity, manages the funds for NOMX DM and OMXCI.

The clearing capital is invested in the form of government securities which are held in two escrow accounts in Danske Bank. In case of default of this bank, the capital would not immediately be accessible due to insolvency procedures. Any liquidity need arising following a default by Danske Bank would have to be handled by utilizing credit facilities with the other liquity provider, SEB and / or excess cash held directly by NOMX STO or its parent company.

Regarding collateral collected as margins, it must be noted that NOMX DM is not allowed to re-use (re-hypothecate/reinvest) it, since collateral is managed by Custodian Institutions on behalf of NOMX DM and pledged (it is not a title of transfer) collateral can legally be seized only in case of member's default.

Concentration limits (Q3) 


\begin{tabular}{|c|c|}
\hline & $\begin{array}{l}\text { As long as the Clearing Capital is invested only in Government Bonds and Bills, the } \\
\text { credit exposure towards a single obligor is limited. The Regulatory Capital Policy } \\
\text { stipulates that no more than } 40 \text { percent of the total regulatory capital may be } \\
\text { invested in mortgage institutions. Additionally, entities are not approved if the entity } \\
\text { itself is clearing member of NOMX DM or forms a part of a Group which is clearing } \\
\text { member of NOMX DM. } \\
\text { The market risk in securities pledged as collateral is managed by imposing } \\
\text { conservative haircuts (see Recommendation 4). The liquidity and credit risk is } \\
\text { managed by setting maximum amounts per pledging counterparty and security in } \\
\text { relation to the observed liquidity in the security and the issuer creditworthiness. }\end{array}$ \\
\hline Assessment & Partly Observed \\
\hline Comments & $\begin{array}{l}\text { NOMX DM has no real time knowledge on the composition of collateral collected } \\
\text { as well as no ex post information on it, except when it conducts a test once in a year. } \\
\text { NOMX DM relies on Custodian Institutions, which are also CCP's members, for } \\
\text { collection of collateral, valuation, application of haircuts, compliance with } \\
\text { concentration limits. Controls on Custodian Institutions are delegated to an outside } \\
\text { body which may conduct inspections. } \\
\text { Investments are made on high quality securities (AAA Swedish government bonds). } \\
\text { But the investment policy is less strict since it allows investment in A rated } \\
\text { securities. } \\
\text { NOMX DM should completely overhaul its current custodian arrangements and rely } \\
\text { on CSDs, in order to be fully sure that the collateral is effectively collected, to have } \\
\text { real time information on the collateral collected and also to have immediate access } \\
\text { to collateral in any cases. It should be noted that NOMX DM is in the process of } \\
\text { setting up a fully new arrangement to collect collateral by 2012, which based on the } \\
\text { draft project should apparently address these weaknesses. } \\
\text { NOMX DM could strengthen its investment policy. The investment policy allows } \\
\text { investment of financial resources in government bonds rated A, while NOMX DM's } \\
\text { current investment practice is to invest them in AAA Swedish government } \\
\text { securities. In view of the need to ensure that financial resources are the most liquid } \\
\text { ones, the investment policy could be to invest only in AAA government securities. }\end{array}$ \\
\hline Recommendation 8. & $\begin{array}{l}\text { A CCP should identify sources of operational risk and minimize them through the } \\
\text { development of appropriate systems, controls and procedures. Systems should be } \\
\text { reliable and secure, and have adequate, scalable capacity. BCPs should allow for } \\
\text { timely recovery of operations and fulfillment of a CCP's obligations. }\end{array}$ \\
\hline Pescription & $\begin{array}{l}\text { Identification and management of operational risk (Q1) } \\
\text { A comprehensive analysis of operational risks is conducted annually and updated } \\
\text { during the year. This is carried out as an integral part of an overall Enterprise Risk } \\
\text { Management (ERM) approach applying to NOMX Group. The ERM approach } \\
\text { covers all types of risks; i.e., strategic, commercial, operational and financial risks } \\
\text { (the input coming from the RMD for these latter ones). This process is supported by } \\
\text { detailed guidelines on how to identify, assess, manage and control risks. The process } \\
\text { is developed and supported by the NASDAQ OMX Global RMD. In accordance } \\
\text { with this, the most recent risk assessment for NOMX DM was conducted in August }\end{array}$ \\
\hline
\end{tabular}


2010.

The result of the review is reported on a bi-annual basis to the Management of NOMX DM and for significant risks also to the Board of NOMX Nordic Exchange Group Limited.

In addition, NOMX DM has adopted Information Security Policies and Standards, established by the NASDAQ OMX Group, that are designed to maintain the confidentiality, integrity and availability of information and which applies to development, maintenance and production of systems within NOMX DM. They also apply to outsourcing partners and third party vendors.

\section{Contingency plans and back-up facilities (Q2)}

Policies for Crisis Management and Business Continuity Management, including supporting guidelines, have been established.

The BCP addresses situations where the operations could become severely disrupted. For example if there is an IT system breakdown or the premises becoming unavailable. Formal incident response procedures have been developed and are tested on a regular basis and carried out with different scenarios.

Procedures for relocating the staff are tested regularly, with a full scale test at least once a year, and critical operation on a more regular basis. The target time for relocation of operations to the back-up site is between 45 and 75 minutes depending on traffic conditions.

The system runs simultaneously on two mirrored sites which are located approximately $15 \mathrm{~km}$ apart with independent infrastructure. Both locations have a high security level both in terms of physical protection from fire or water etc, as well as any unauthorized access or other external threats. To further add to the security level, both locations also have its own power supply in order to ensure protection from power grid blackouts.

As there are two completely mirrored sites, no data will be lost during a breakdown. In case of one of the sites going down, all users connected to the site still running will remain connected. NOMX DM conducts a yearly review of its business continuity plan, including emergency tests twice a year.

\section{Adequate management controls and periodic independent audit (Q3)}

Manual as well as automated control procedures have been built into the day-to-day clearing- and settlement process to reveal any operational risk issues at an early stage. These procedures are reviewed on a continuous basis.

Management and significant members of the staff are actively involved in NOMX DM's periodic operational risk reviews, mainly through risk self-assessment activities. A complete and all-encompassing risk review of business operations are conducted on an annual basis.

All new product launches are since Q3 2010 being vetted in a New Product Risk Committee at NOMX Group level before launch. The vetting procedure requires a complete risk assessment to be presented to the committee for approval. It has not yet been applied to new products launched by NOMX DM.

Historical loss data is tracked and trends are analyzed in a formal manner. The outcome of operational risk assessment activities are reported to management and 


\begin{tabular}{|c|c|}
\hline & $\begin{array}{l}\text { reviewed by management at follow-up meetings. } \\
\text { The Internal Audit function of the parent company NOMX is responsible for making } \\
\text { independent reviews of the adequacy of operational risk controls within NOMX } \\
\text { DM. Internal Audit performs continuous reviews of the adequacy of operational risk } \\
\text { controls based on an annual audit plan. } \\
\text { Availability and scalability of the system (Q4) } \\
\text { The target for availability of the clearing system is } 99,90 \text { percent and in } 2010 \text {, the } \\
\text { outcome was } 99,99 \text { percent. } \\
\text { NOMX DM has outsourced parts of the IT responsibilities to an internal business } \\
\text { area within NOMX called Global IT Services ("GITS"). NOMX DM have the } \\
\text { overall responsibility for the strategic and operational IT issues related to trading, } \\
\text { clearing and settlement while the technical operation and surveillance part are } \\
\text { outsourced to GITS, but critical IT systems are not shared with other NOMX } \\
\text { entities. } \\
\text { NOMX DM uses a technical solution based on connection with a dedicated line or } \\
\text { VPN. The application in use, HP RTR (Reliable transaction Router for Open VMS) } \\
\text { handles the integrity of the transaction. This solution provides an application- } \\
\text { disaster tolerance with transaction integrity and real-time transaction } \\
\text { Service level agreements have been established between NOMX DM and GITS } \\
\text { specifying the performance requirements concerning normal operations, and also } \\
\text { needed response procedures in case of operational disruptions. The performance } \\
\text { level is evaluated in monthly reports. Tests are performed on a regular basis where } \\
\text { the maximum capacity is tested. }\end{array}$ \\
\hline Assessment & Observed \\
\hline Comments & \\
\hline Recommendation 9. & $\begin{array}{l}\text { A CCP should employ money settlement arrangements that eliminate or strictly limit } \\
\text { its settlement bank risks, that is, its credit and liquidity risk from the use of banks to } \\
\text { effect money settlements with its participants. Funds transfers to a CCP should be } \\
\text { final when effected. }\end{array}$ \\
\hline Description & $\begin{array}{l}\text { Use of central bank money (Q1) } \\
\text { NOMX DM uses the central bank model for settlements in SEK and DKK, and the } \\
\text { private settlement agent model for settlement in EUR, NOK, and USD. About } 99 \\
\text { percent of the cash settlements are made in SEK and DKK. Thus only a minor } \\
\text { portion of cash settlements takes place in EUR, NOK, and USD, in the settlement } \\
\text { banks used by NOMX DM. } \\
\text { Cash settlements in SEK are settled in the RB's payment system, RIX, on the } \\
\text { settlement day. Members that are not participants in the RIX payment system must } \\
\text { use a settlement bank that is a member to fulfill their obligations with respect to } \\
\text { settlement. Clearing members must ensure that the settlement bank has the necessary } \\
\text { balance for cash settlement at its disposal no later than } 11.30 \text { CET on the settlement } \\
\text { day. } \\
\text { Settlements in DKK are settled on the settlement day through the Denmark central } \\
\text { bank's payment system KRONOS, of which NOMX DM is a participant.. Members } \\
\text { that are not participants in KRONOS must use a settlement bank that is a member to }\end{array}$ \\
\hline
\end{tabular}




\begin{tabular}{|c|c|}
\hline & $\begin{array}{l}\text { fulfill their obligations with respect to settlement. Clearing members must ensure } \\
\text { that the settlement bank has the necessary balance of cash settlement for disposal on } \\
\text { NOMX DM's KRONOS account no later than 11:00 CET on the settlement day. } \\
\text { The settlement banks used by NOMX DM are SEB and Nordea. Settlements in EUR } \\
\text { are mainly settled in SEB (Finland), but may also be settled in Nordea, as a backup } \\
\text { facility. Settlements in NOK were mainly settled in Nordea (Norway) until the end } \\
\text { of } 2010 \text {, when NOMX DM changed to SEB (Norway) as the main settlement bank } \\
\text { for NOK settlement. } \\
\text { Finality of transfers (Q2) } \\
\text { All countries where settlement banks engaged by NOMX DM are situated, i.e., } \\
\text { Sweden, Denmark, Norway, Finland and UK, have implemented the Settlement } \\
\text { Finality Directive. } \\
\text { All payment systems for the currency used for daily settlement by NOMX DM } \\
\text { provide intraday finality. } \\
\text { NOMX DM continuously verifies that all cash settlements in all currencies are } \\
\text { effected in accordance with the instructions from the settlement system. NOMX DM } \\
\text { verifies that the settlements in SEK are accurate at the cut-off time in RIX (11:45). } \\
\text { On a daily basis NOMX DM also verifies that all payments in NOK, DKK, EUR are } \\
\text { in place in accordance with local cut-off time 12:00 am. } \\
\text { Criteria for selection of settlement banks (Q3) } \\
\text { NOMX DM uses settlement banks with a minimum rating level A- in order to } \\
\text { ensure the settlement agents creditworthiness. It is required that they have a system } \\
\text { that supports intraday intercompany payments and daily account balance statements. }\end{array}$ \\
\hline Assessment & Observed \\
\hline Comments & \\
\hline Recommendation 10. & $\begin{array}{l}\text { A CCP should clearly state its obligations with respect to physical deliveries. The } \\
\text { risks from these obligations should be identified and managed. }\end{array}$ \\
\hline Description & $\begin{array}{l}\text { CCP obligations for physical delivery (Q1) } \\
\text { Based on the R\&R (section 3.10), NOMX DM commits itself to deliver the assets to } \\
\text { the buying counterparty, even in case of default of the selling clearing member. In } \\
\text { this case, NOMX DM has to buy the securities with a view to deliver them to the } \\
\text { buying clearing member in lieu of the defaulter. However NOMX DM does not } \\
\text { commit to fulfill the transaction on the original settlement date if the original } \\
\text { counterparty cannot fulfill its obligation. In such a case NOMX DM has the right to } \\
\text { do a buy in of shares in accordance with the R\&R or take other measures to } \\
\text { complete the delivery. } \\
\text { DVP of mitigation of principal risks (Q2) } \\
\text { Deliveries of stocks and fixed income products resulting from exercise or expiration } \\
\text { are effected in the CSDs in the local country. Deliveries are always effected in } \\
\text { accordance with the principle of DVP thus eliminating the risk of delivery without } \\
\text { payment. } \\
\text { All Swedish deliveries take place via NOMX DM's account in the Swedish } \\
\text { settlement system, Euroclear Sweden. The system guarantees final and irrevocable }\end{array}$ \\
\hline
\end{tabular}




\begin{tabular}{|c|c|}
\hline & $\begin{array}{l}\text { settlement through DVP. NOMX DM sends all delivery instructions to Euroclear } \\
\text { Sweden automatically. The members match all deliveries in the Euroclear Sweden's } \\
\text { system. } \\
\text { Deliveries of Danish stocks and Finnish stocks takes place in a similar way as } \\
\text { Swedish securities, respectively with the Danish CSD, VP SECURITIES (VP), and } \\
\text { the Finnish CSD, Euroclear Finland. } \\
\text { Deliveries of Norwegian stocks take place through the Norwegian system (VPS). } \\
\text { NOMX DM is not a member of VPS and therefore all deliveries are carried out } \\
\text { through a custody bank, SEB (NOMX DM changed from Nordea to SEB in the end } \\
\text { of 2010), engaged by NOMX DM. } \\
\text { In cases where the members fail to deliver or buy, NOMX DM has the right to } \\
\text { charge margins for the unsettled instructions. Any additional cost as a result of late } \\
\text { or failing delivery can be passed on to the counterparty that has failed in its } \\
\text { obligation. } \\
\text { NOMX DM has securities loan agreements with two banks, SEB and Nordea, to } \\
\text { guarantee delivery to the receiving counterparty. NOMX DM also has the facility to } \\
\text { buy in shares from these two banks, if required. }\end{array}$ \\
\hline Assessment & Observed \\
\hline Comments & \\
\hline Recommendation 11. & $\begin{array}{l}\text { CCPs that establish links either cross-border or domestically to clear trades should } \\
\text { evaluate the potential sources of risks that can arise, and ensure that the risks are } \\
\text { managed prudently on an ongoing basis. There should be a framework for } \\
\text { cooperation and coordination between the relevant regulators and overseers. }\end{array}$ \\
\hline Description & NOMX DM does not have any link established to other CCP. \\
\hline Assessment & NA \\
\hline Comments & \\
\hline Recommendation 12. & $\begin{array}{l}\text { While maintaining safe and secure operations, CCPs should be cost-effective in } \\
\text { meeting the requirements of participants. }\end{array}$ \\
\hline Description & $\begin{array}{l}\text { Procedures to control risks and pricing (Q1) } \\
\text { NOMX DM has a budgetary process in place to control its costs. NOMX DM } \\
\text { benchmarks its costs and prices with other exchanges and CCPs but considers it } \\
\text { difficult to carry out meaningful comparisons due to the fact that costs are either not } \\
\text { public information or are not provided with enough details. NOMX DM also } \\
\text { considers that comparisons are made difficult by the fact that clearinghouses have a } \\
\text { default fund or own capital to cover losses and may clear only one or several } \\
\text { exchanges. } \\
\text { Regular review of service levels and operational reliability (Q2) } \\
\text { In order to understand customer needs and requirements of the participants, NOMX } \\
\text { reviews its service levels through different channels. } \\
\text { The major channel is the regular direct contact NOMX has with participants through } \\
\text { account managers. During these bilateral meetings, suggestions and ideas for } \\
\text { improvements are discussed. }\end{array}$ \\
\hline
\end{tabular}




\begin{tabular}{|c|c|}
\hline & $\begin{array}{l}\text { Another channel used to review the service levels is customer satisfaction surveys, } \\
\text { which have been conducted on a regular basis since 2004. The latest survey was } \\
\text { conducted in spring 2010, where Nordic customers gave an average rating of } 3.5 \\
\text { (scale 1-5 with } 5 \text { being the highest) on the statement "Overall impression of } \\
\text { NASDAQ OMX." It can be noted that no specific question related to clearing was } \\
\text { asked, all question focusing on the trading side. } \\
\text { NOMX STO organizes different fora, targeting different customer groups, but where } \\
\text { clearing activities are rarely discussed: } \\
\text { - Derivatives Market Committee meetings, eight times per year, arranged together } \\
\text { with the local Securities Dealers Associations, where trading, equity product } \\
\text { related issues and suggestions for rule changes are discussed; } \\
\text { - Fixed Income Advisory Board, four times per year, where issues concerning the } \\
\text { fixed income market are brought up to discussion with the largest members; } \\
\text { Operations Forum, where suggestions regarding clearing operations business, } \\
\text { system changes and products can be expressed; } \\
\text { - Risk Management Forum, where participants have the possibility to bring up } \\
\text { suggestions regarding risk management, and which is rarely held; } \\
\text { - IT Forum for discussions about IT related issues; and } \\
\text { Meetings with Securities Dealers Association and its IT group consisting of the } \\
\text { major members, to address when needed major upcoming technical changes or } \\
\text { serious technical incidents. } \\
\text { The Board of Directors is provided with different reports on operational reliability at } \\
\text { each board meeting. }\end{array}$ \\
\hline Assessment & Observed \\
\hline Comments & \\
\hline Recommendation 13. & $\begin{array}{l}\text { Governance arrangements for a CCP should be clear and transparent to fulfill public } \\
\text { interest requirements and to support the objectives of owners and participants. In } \\
\text { particular, they should promote the effectiveness of a CCP's risk management } \\
\text { procedures. }\end{array}$ \\
\hline Description & $\begin{array}{l}\text { Clarity and transparency of governance arrangements (Q1) } \\
\text { The decisions relating to the operations of NOMX DM are the responsibility of the } \\
\text { Board of Directors of NOMX STO. This company is fully owned by NASDAQ } \\
\text { OMX Nordic Limited which has a steering and coordinating role for Nordic } \\
\text { operations. This latter company is fully owned by The NASDAQ OMX Group, Inc } \\
\text { (see organizational Figure 1) through a chain of holding companies. } \\
\text { The Board of Directors of NOMX STO shall adhere to common policies and } \\
\text { guidelines within the NASDAQ OMX Group, and more specifically, to the policies } \\
\text { and guidelines within the NASDAQ OMX Nordic sub-group. In doing so, the Board } \\
\text { of Directors has an obligation to assess that they are appropriate for the purpose. } \\
\text { The parent company NASDAQ OMX Nordic Limited has a general responsibility to } \\
\text { monitor that its subsidiaries, of which NOMX STO, implement group company } \\
\text { policies, are compliant with capital market legislation. Incentives are also decided } \\
\text { by the NASDAQ OMX Nordic Limited. Decision about policy documents are made } \\
\text { both by the board of directors at the Nordic level as well as in the licensed legal } \\
\text { entity. The Nordic board informs the board of NOMX STO about which measures }\end{array}$ \\
\hline
\end{tabular}


should be taken according to what has been stated above. The board of NOMX STO should inform the Nordic board about significant matters.

According to the Rules of Procedures adopted by the Board of Directors, it is the board that shall make decisions on amendments to the $R \& R$ where the amendment is of major importance. The Board of Directors has adopted a Regulatory Capital Policy and a Clearing Policy (see recommendation 5) and instructions for the Clearing Risk Committee and the Clearing Default Committee, to which material issues relating to NOMX DM's risk management procedures have been delegated.

Furthermore, the Board of Directors has delegated certain powers to the President by way of issuing Instructions for the President. The President shall among other things make decisions regarding amendments to the $\mathrm{R} \& \mathrm{R}$, provided that the amendments are not of major importance.

The legal structure relating to NOMX DM as well as the composition of the Board of Directors of NOMX STO and NASDAQ OMX Nordic Limited are disclosed on NASDAQ OMX's web site.

All members, including remote members who are not represented by the Swedish Securities Dealers Association, are welcome to provide feedback and comments regarding changes to the $R \& R$.

Separation between reporting lines for risk management and other operations (Q2)

The Risk Management function is separated from the business lines of the CCP. The head of RMD reports to the NASDAQ OMX Group treasurer who is responsible for financial risks on group level and reports to the group CFO. He is also responsible for risk reporting to the Board of NOMX STO and NASDAQ OMX Nordic Limited.

The NOMX DM Clearing Risk Committee is the single decision making authority concerning risk matters applying to the CCP and in case of a member's default the NOMX DM Clearing Default Committee is the single decision making authority. New markets and products need approval by the Clearing Risk Committee. The head of the RMD has veto power in both the Clearing Risk Committee and the Clearing Default Committee.

It can also be noted that Internal Audit within NOMX STO reports to Nordic Limited and Internal Audit head of department in NY and head of Global risk Management in Stockholm, which is a division having the role of consolidating risks (notably operational risks, business risks in addition to financial risks which are deals with by the RMD) and reports to the head in NY who itself reports to the CFO in NY.

\section{Management incentives skills and accountability (Q3)}

The Board is formally appointed by the general meeting of NOMX STO. NOMX STO's Board consists of five executives who are all senior managers of NASDAQ OMX Group.Board members are subject by law to a fit and proper test by FI.

Clearing risk related issues are reported to the Board of Directors continuously. Further, operational incidents, claims \& litigation issues and compliance issues, as well as capital adequacy assessment, are reported regularly to the Board.

The Board of Directors has approved the Rules of Procedure for the Board of Directors and Instructions for the President and the risk committees, which describe 


\begin{tabular}{|c|c|}
\hline & 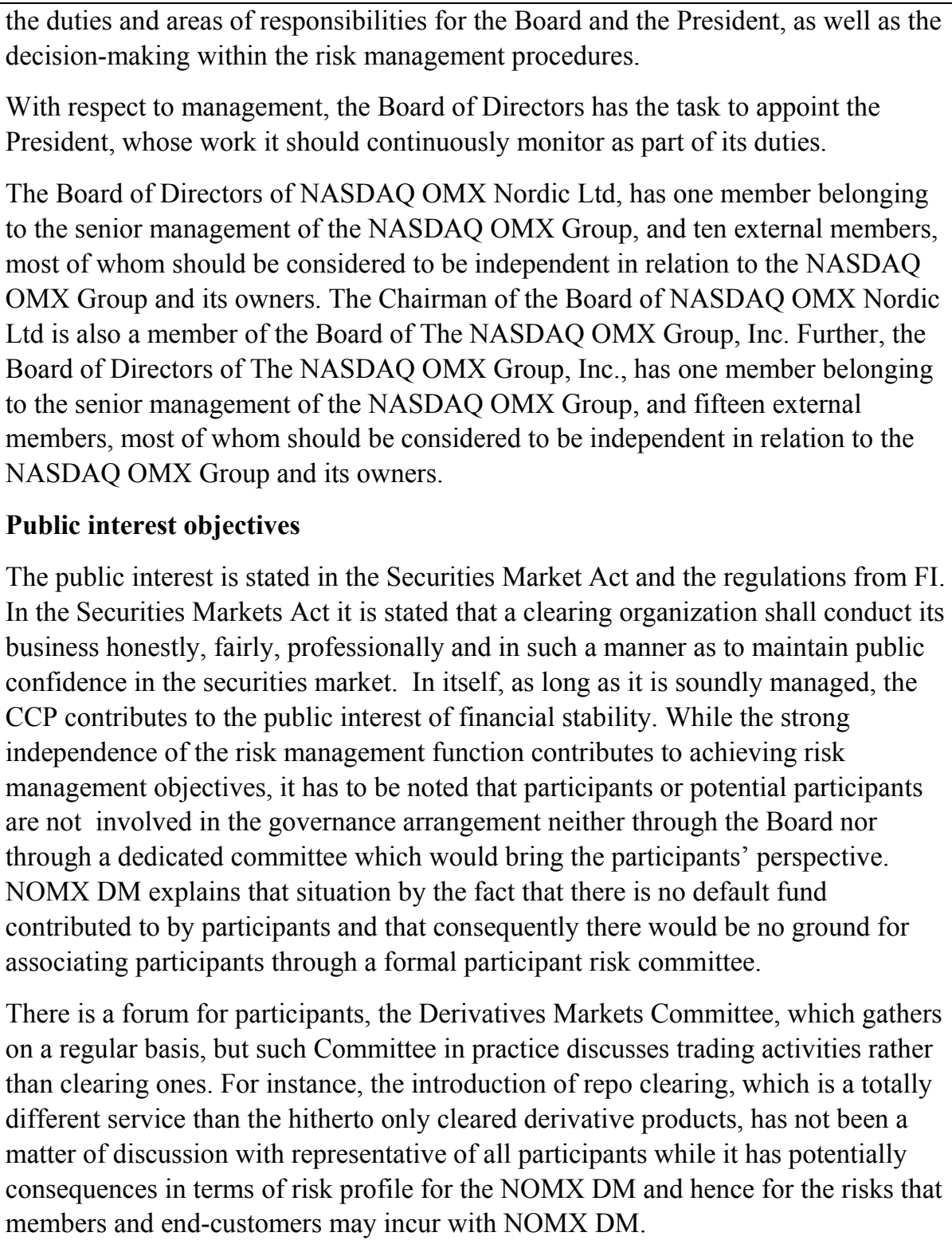 \\
\hline Assessment & Broadly Observed \\
\hline Comments & $\begin{array}{l}\text { Governance arrangements of NOMX DM are clearly specified and information } \\
\text { about them is publicly available on the website. The governance arrangements } \\
\text { support robust risk management by a separation in the reporting lines between risk } \\
\text { management and other operations. In both the Clearing risk committee and the } \\
\text { Default committee, the head of risk management has a veto power. The Board and } \\
\text { the management are accountable for NOMX DM's performance, including } \\
\text { delivering sound risk management. } \\
\text { However, there is a lack of users' feedback and involvement through consultative } \\
\text { user groups. NOMX DM does not sufficiently request feedback on its clearing } \\
\text { services from members on a multilateral basis. Participants are not represented on } \\
\text { NOMX STO Board or through participant committees within NOMX DM that } \\
\text { would bring their specific perspectives and interests. }\end{array}$ \\
\hline
\end{tabular}




\begin{tabular}{|c|c|}
\hline & $\begin{array}{l}\text { NOMX DM should enhance member's involvement in clearing activities through } \\
\text { their adequate representation, for instance through a formal advisory committee. }\end{array}$ \\
\hline Recommendation 14. & $\begin{array}{l}\text { A CCP should provide market participants with sufficient information for them to } \\
\text { identify and evaluate accurately the risks and costs associated with using its } \\
\text { services. }\end{array}$ \\
\hline Description & $\begin{array}{l}\text { Disclosure of risk management information (Q1) } \\
\text { NOMX DM provides extensive information on its website. In addition to the R\&R, } \\
\text { more straightforward information is also provided. For instance, in the publication } \\
\text { "NOMX DM as a Counterparty," NOMX DM provides a clear description of its } \\
\text { operations, participants' rights and obligations towards NOMX DM, default process } \\
\text { as well as the risk management activities. NOMX DM publishes clearing activities } \\
\text { on an annual, monthly and daily basis depending on the information, which include } \\
\text { statistics such as turnover and outstanding contracts, settlement-related statistics and } \\
\text { system availability. } \\
\text { All members applying for membership of NOMX DM are required to have } \\
\text { personnel that have completed courses and examinations for the systems used for } \\
\text { trading and clearing at NOMX DM before they are accepted as members. These } \\
\text { courses are arranged by NOMX DM and contain one part of system knowledge and } \\
\text { training and one part that describes the R\&R and clearing routines including risk } \\
\text { related issues. } \\
\text { Accessibility of information (Q2) } \\
\text { The documentation is available both in Swedish and in English on the website. } \\
\text { Completion and disclosurof the answers to the key questions of RCCPs (Q3) } \\
\text { The answers to the key questions of RCCPs are published on NOMX DM web site. } \\
\text { They are reviewed on a yearly basis. }\end{array}$ \\
\hline Assessment & Observed \\
\hline Comments & \\
\hline Recommendation 15 & $\begin{array}{l}\text { A CCP should be subject to transparent and effective regulation and oversight. In } \\
\text { both a domestic and an international context, central banks and securities regulators } \\
\text { should co-operate with each other and with other relevant authorities. }\end{array}$ \\
\hline Description & $\begin{array}{l}\text { Effective regulation and oversight (Q1) } \\
\text { FI and RB are respectively in charge of supervising and overseeing NOMX DM. } \\
\text { Based on the Swedish Securities Market Act the conduct of clearing activities } \\
\text { requires licensing. NOMX STO has been granted such a license by FI, which also } \\
\text { exercises supervision. In order to conduct this supervision, FI possesses the right to } \\
\text { demand the information deemed necessary, both from NOMX DM and from other } \\
\text { parties. FI also possesses the right to conduct on site investigations. FI's rights are } \\
\text { stipulated in the Swedish Securities Market Act, the Swedish Financial Instruments } \\
\text { Trading Act and the Swedish Act on Systems for Settlement of Obligations on the } \\
\text { Financial Market. } \\
\text { The basis of the RB's supervisory role is formed by the Sveriges Riksbank Act, } \\
\text { according to which the RB is responsible for the promotion of a safe and efficient } \\
\text { payment system. In addition, the RB is empowered to act as a lender of last resort, in }\end{array}$ \\
\hline
\end{tabular}


the form of credits granted under special terms and conditions. The Sveriges Riksbank Act also provides the RB with the right to demand from institutions any information the RB deems necessary for its supervisory activities.

It can be noted that no formal approval process is stated in the legislation for R\&R. However changes to the $R \& R$ are communicated to FI. In cases where according to the current legislation there is a change in the $R \& R$ which is not in compliance with the relevant legislation, FI would raise the issue and handle it in accordance with common procedures within the authority.

\section{Sufficient legal capacity and resources}

Within FI, the supervision of clearing organizations (as well as stock exchange) is primarily carried out by a supervisory group of five individuals within the Markets Department Licensing matters and support in legal issues are dealt with by the responsible legal unit within the Markets Department. Issues of supervision and analyses of particular risk areas are handled by various risk analysis units.

Within RB, the Financial Infrastructure Division of the Financial Stability Department deals with the oversight of financial infrastructures. Of the total of nine individuals working within this unit, three work on clearing and settlement issues. In addition, specialist skills within the areas of risk management, law and IT are also available within RB.

\section{Definition and disclosure of objectives of central banks and securities regulators (Q2)}

FI is an authority responsible for the supervision of financial markets, marketplaces and financial companies. Its overall objective is to contribute to the stability and efficiency of the financial system and to work for effective consumer protection. In order to achieve these goals, FI draws up rules for financial operations, grants licenses, exercises supervision and analyses changes in the external environment. Companies under the supervision of FI include banks and other credit institutions, securities companies, trusts and fund management companies, stock exchanges, clearing organizations and insurance companies.

NOMX STO (as such including NOMX DM) is currently part of the most highly prioritized companies by FI in terms of supervision with the four major banking groups and Euroclear Sweden, the reason being that they are deemed to have a significant impact on the financial market. FI's overall objectives and operational focus are presented in the annual report and operational focus documentation, among others. These documents are available on FI website.

A presentation of the RB's view of its mandate was published in 1997 and a description of the RB's supervisory role was published in 2001. Both of these publications, as well as speeches and responses to consultations dealing with the financial markets, are available from the RB's website.

The supervision and oversight includes assessing NOMX DM as a CCP in securities clearing in accordance with the European System of Central Banks (ESCB) and the Committee of European Securities Regulators (CESR)' Recommendations for CCPs. The result of the RB's work in the supervision of NOMX DM is presented annually in the Financial Stability report. The complete results of the assessment of NOMX DM are also available on the RB's website. 
Timely provision of oversight information to relevant authorities (Q3).

FI regularly meets with representatives of NOMX STO to review all changes in operations, according to a fixed agenda, covering, amongst other points, changes in products and services, organization, systems and rules and regulations. NOMX STO reports financial information to FI each quarter. In accordance with FI's general guidelines, NOMX STO has a reporting obligation as regards significant events, such as any failure by NOMX STO to fulfill its commitments to its clients or the occurrence of faults in the technical systems. NOMX STO is also subject to this reporting obligation as regards outsourced operations. A prerequisite for outsourcing is that FI has full insight, via NOMX STO. FI has the right to ask for any information related to the activities of NOMX. FI is in regular contact with NOMX and NOMX regularly informs FI about changes that could affect the status of their license. NOMX is by law required to fulfill the capital requirements at all times.

Based on the Sveriges Riksbank Act, the RB has the right to demand any information that the RB deems necessary to the exercise of its mandate. In order to collect this information, the RB utilizes:

- quarterly meetings, at which representatives of the RB meet with representatives of NOMX STO to discuss NOMX DM's operations as CCP. These meetings focus upon NOMX DM's activities, systems operation and risk management.

- analysis of the availability of the clearing system in the RIX system. As the cash settlement of NOMX DM is effected in the RB's payment system, RIX, the system's technical robustness can be analyzed on the basis of availability in RIX.

- an annual assessment of NOMX DM as CCP, in accordance with international standards. This entails an annual update by NOMX STO of the information provided to the RB for this purpose.

\section{Domestic and cross-border cooperation (Q4)}

In 2003, the RB and FI signed an agreement covering cooperation in issues of financial stability. In 2005, this agreement was amended, for example, to also include the Swedish Ministry of Finance (MoF). This agreement has enabled the authorities to unite over guidelines for consultations and the exchange of information in their work on financial stability and crisis management. In 2005, the $\mathrm{RB}$ and FI decided to extend their cooperation to include a joint assessment of the Swedish clearing and settlement systems. Accordingly, collaboration among the authorities has been intensified through a more comprehensive exchange of both information and working methods.

FI has signed special agreements with the Finnish, Danish and Norwegian supervisory authorities regarding collaboration in the supervision of the stock exchange and clearing activities of the NASDAQ OMX Group. The aim of this collaboration is to ensure effective and comprehensive insight. The authorities hold regular meetings for the exchange of information, consult in cross-border matters and can perform joint inquiries.

However it is not fully clear what the respective exact responsibilities of Norwegian and Swedish authorities towards NOMX COM, both in normal times and in case of crisis, are: the Norwegian FSA seems to have responsibility because NOMX COM serves a Norwegian market it has authorized; FI is responsible because NOMX COM is within the legal entity NOMX STO (as a branch) which falls under its 


\begin{tabular}{|c|c|}
\hline & $\begin{array}{l}\text { responsibility. While informal contacts seem good between FI and the Norwegian } \\
\text { FSA, knowledge and understanding of activities operated by NOMX COM by } \\
\text { Swedish authorities is not entirely adequate, though NOMX COM may have } \\
\text { spillover effects on NOMX DM due to the fact that both CCPs are within the same } \\
\text { legal entity and share the same regulatory capital. }\end{array}$ \\
\hline Assessment & Broadly Observed \\
\hline Comments & 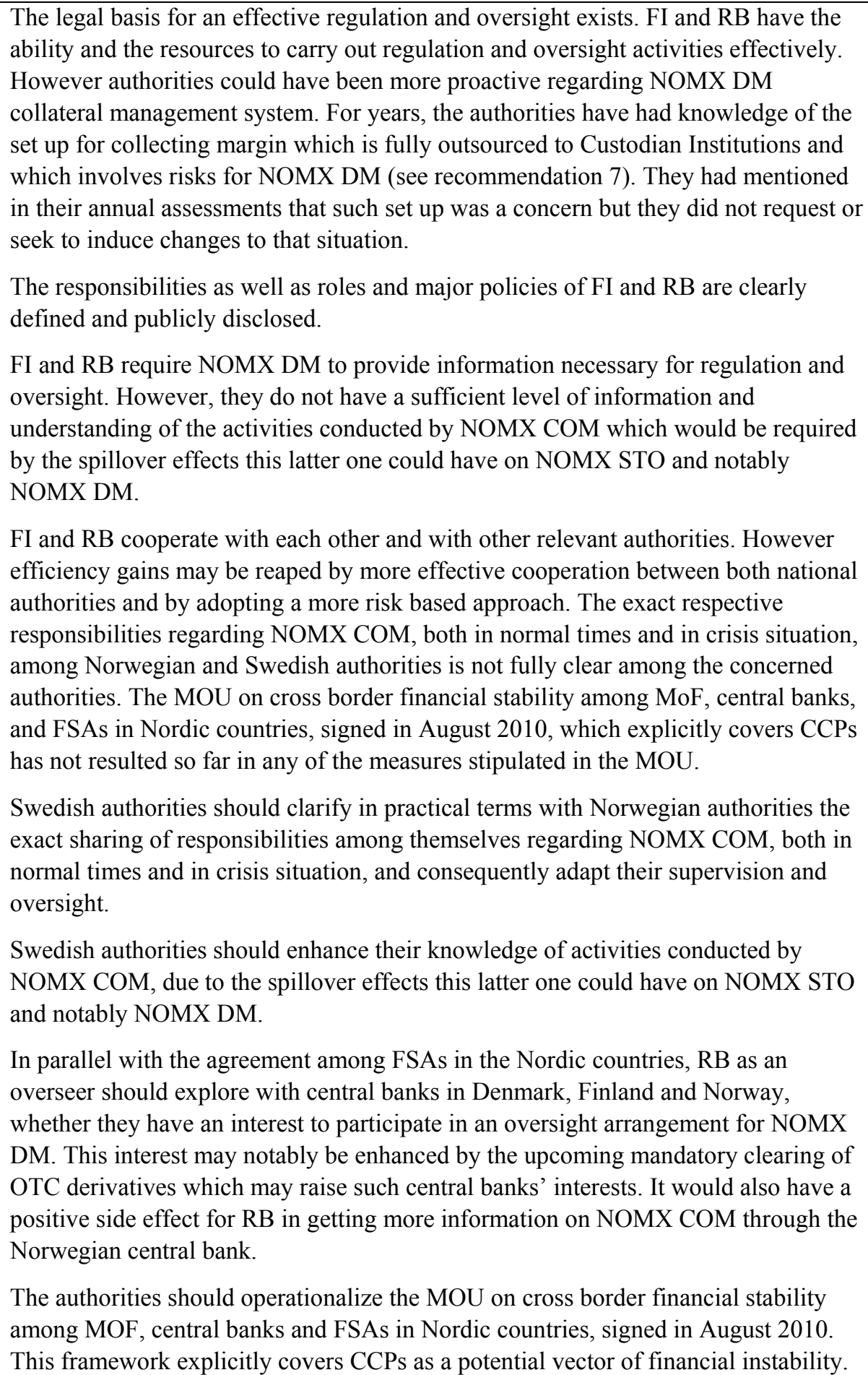 \\
\hline
\end{tabular}




\begin{tabular}{|l|l|}
\hline $\begin{array}{l}\text { The authorities should operationalize it through providing information on a regular } \\
\text { basis to all concerned authorities based on the template for sharing of information } \\
\text { annexed to the MOU. } \\
\text { While informal contacts between FI and RB seem good, authorities should formalize } \\
\text { the routines and procedures of their cooperation in order to increase exchange of } \\
\text { information, to possibly share or allocate specific tasks among themselves, to } \\
\text { enhance their common analysis capacity, and to gain efficiency beneficial for both } \\
\text { parties. As an example for information sharing, this routine could comprise common } \\
\text { reporting requirements that would allow the authorities to get regular and frequent } \\
\text { updated data from NOMX DM. } \\
\text { Authorities should analyze whether an annual assessment is necessary or whether a } \\
\text { less frequent review could be contemplated in order to jointly dedicate more time } \\
\text { and attention to issues of significant importance, thus adopting a more risk based } \\
\text { approach. } \\
\text { Authorities should strive to strengthen their staffing resources with skills in } \\
\text { quantitative analysis in order to be in a position to directly assess (and/or be able to } \\
\text { critically review reports which are ordered to external consultants) quantitative } \\
\text { models used to calculate margins and financial resources. }\end{array}$ \\
\hline
\end{tabular}




\section{Table 3. Summary of the Detailed Assessment of the Observance of NOMX DM with the CPSS-IOSCO Recommendations for Central Counterparties}

\begin{tabular}{|c|c|c|}
\hline Responsibility & Grading & Comments \\
\hline \multicolumn{3}{|l|}{ Legal risk } \\
\hline $\begin{array}{l}\text { 1. CCPs should have a well-founded, clear } \\
\text { and transparent legal basis in the relevant } \\
\text { jurisdiction. }\end{array}$ & $\mathrm{O}$ & $\begin{array}{l}\text { The laws and regulations governing the operations of } \\
\text { NOMX DM, its rules and contractual provisions for its } \\
\text { participants are clearly stated and are readily accessible } \\
\text { to participants and the public. The legal framework } \\
\text { demonstrates a high degree of assurance that there is a } \\
\text { clear and effective legal basis for NOMX DM's } \\
\text { operations and risk management procedures. The rules } \\
\text { and contracts of NOMX DM are enforceable in the } \\
\text { case of the insolvency of NOMX DM's participants, } \\
\text { and there is a high degree of assurance that actions } \\
\text { taken under such rules may not be later stayed, avoided } \\
\text { or reversed. } \\
\text { However in order to ensure the coherence of rules with } \\
\text { time, the FI's approval of changes in the R\&R would } \\
\text { provide further confidence in maintaining such } \\
\text { coherence. }\end{array}$ \\
\hline \multicolumn{3}{|l|}{ Participation requirement } \\
\hline $\begin{array}{l}\text { 2. A CCP should require participants to } \\
\text { have sufficient financial resources and } \\
\text { robust operational capacity to meet } \\
\text { obligations arising from participation in the } \\
\text { CCP. A CCP should have procedures in } \\
\text { place to monitor that participation } \\
\text { requirements are met in an on-going basis. } \\
\text { A CCP's participation requirements should } \\
\text { be objectives, publicly disclosed, and permit } \\
\text { fair and open access. }\end{array}$ & $\mathrm{BO}$ & $\begin{array}{l}\text { NOMX DM has established membership requirements } \\
\text { to ensure that its members have sufficient financial } \\
\text { resources and robust operational capacity to ensure } \\
\text { timely performance by its members. NOMX DM has } \\
\text { procedures in place to monitor participation } \\
\text { requirements are met on an ongoing basis. } \\
\text { Participation requirements are objective, permitting } \\
\text { fair and open access and there are no requirements that } \\
\text { limit access on grounds other than risks and } \\
\text { participation requirements are clearly stated and } \\
\text { publicly disclosed. } \\
\text { However, direct pledge end customers, that have direct } \\
\text { relationships with NOMX DM, are not subject to } \\
\text { specific requirements though NOMX DM has direct } \\
\text { counterparty risk with them. }\end{array}$ \\
\hline \multicolumn{3}{|l|}{$\begin{array}{l}\text { Measurement and management of credit } \\
\text { exposures }\end{array}$} \\
\hline $\begin{array}{l}\text { 3. A CCP should measure its credit } \\
\text { exposure to its participants at least once a } \\
\text { day. Through margin requirements, other } \\
\text { risk control mechanisms or a combination of } \\
\text { both, a CCP should limit its exposure to }\end{array}$ & $\mathrm{O}$ & $\begin{array}{l}\text { NOMX DM measures exposures of members on an } \\
\text { intraday basis and at the end of the day. The } \\
\text { information on which the calculations are based is } \\
\text { timely. Based on these measures, NOMX DM call }\end{array}$ \\
\hline
\end{tabular}




\begin{tabular}{|c|c|c|}
\hline Responsibility & Grading & Comments \\
\hline $\begin{array}{l}\text { potential losses from defaults of its } \\
\text { participants in normal market conditions so } \\
\text { that the operation of the CCP would not be } \\
\text { disrupted and non-defaulting participants } \\
\text { would not be exposed to losses that they } \\
\text { cannot anticipate or control. }\end{array}$ & & $\begin{array}{l}\text { margins at the end of the day and on an intraday basis } \\
\text { when margin requirements hit a threshold of } 200 \text { mio } \\
\text { SEK. }\end{array}$ \\
\hline \multicolumn{3}{|l|}{ Margin requirements } \\
\hline \multirow[t]{2}{*}{$\begin{array}{l}\text { 4. If a CCP relies on margin requirements } \\
\text { to limit its credit exposures to participants, } \\
\text { these requirements should be sufficient to } \\
\text { cover potential exposures in normal market } \\
\text { conditions. The models and parameters used } \\
\text { in setting margin requirements should be } \\
\text { risk-based and reviewed regularly. }\end{array}$} & $\mathrm{BO}$ & $\begin{array}{l}\text { The margin requirements set by NOMX DM cover its } \\
\text { potential exposures to its clearing members' positions } \\
\text { in normal market conditions. NOMX DM bases the } \\
\text { models and the parameters used in determining margin } \\
\text { requirements on the risk characteristics of the products } \\
\text { cleared. NOMX DM regularly validates coverage of } \\
\text { the models and the parameters. NOMX DM makes } \\
\text { intraday margin calls. }\end{array}$ \\
\hline & & $\begin{array}{l}\text { NOMX DM accepts as collateral to meet margin } \\
\text { requirements bank guarantees which by definition are } \\
\text { not liquid resources. In addition, these bank guarantees } \\
\text { are provided by banks which are also NOMX DM's } \\
\text { members, while two of them are the sole liquidity } \\
\text { providers. In addition there is a risk of sectorial } \\
\text { concentration of the collected collateral: for instance } \\
\text { banks may represent about } 30 \text { percent of collected } \\
\text { collateral on a specific day. }\end{array}$ \\
\hline \multicolumn{3}{|l|}{ Financial resources } \\
\hline $\begin{array}{l}\text { 5. A CCP should maintain sufficient } \\
\text { financial resources to withstand, at a } \\
\text { minimum, the default of a participant to } \\
\text { which it has the largest exposure in extreme } \\
\text { but plausible market conditions. }\end{array}$ & $\mathrm{PO}$ & $\begin{array}{l}\text { Based upon its stress test procedures, NOMX DM has } \\
\text { sufficient financial resources to withstand at a } \\
\text { minimum a default by the clearing member to which it } \\
\text { has the largest exposure in extreme but plausible } \\
\text { market conditions. Indeed the stress test encompasses } \\
\text { an assumption of simultaneous default of the two } \\
\text { members with the largest exposures. } \\
\text { However, both CCPs within NOMX STO share the } \\
\text { same "regulatory capital" dedicated to cover losses in } \\
\text { case of a member's default. This means that though } \\
\text { both CCPs do not share the same participants (only a } \\
\text { few are in common and not active in both) and treat } \\
\text { very different products, they share the same financial } \\
\text { protection to face extreme losses. As a consequence, } \\
\text { difficulties in one of them would spillover on to the } \\
\text { other one. } \\
\text { Financial resources set aside to face extreme losses are } \\
\text { brought by NOMX STO and ring-fenced, but through a } \\
\text { highly complex mechanism from the legal entity }\end{array}$ \\
\hline
\end{tabular}




\begin{tabular}{|c|c|c|}
\hline Responsibility & Grading & Comments \\
\hline & & $\begin{array}{l}\text { balance sheet. The "clearing capital" ( } 1,970 \text { mio SEK) } \\
\text { is only partly funded and its coverage is very complex, } \\
\text { with the use of insurance guarantee, itself being } \\
\text { guaranteed by a bank guarantee, with securities being } \\
\text { collateralized. This structure raises several concerns: } \\
\text { high complexity which potentially may result in legal } \\
\text { uncertainty and delay in having access to the funds in } \\
\text { case of needs. } \\
\text { The financial resources do not provide a sufficiently } \\
\text { reliable liquidity level. Liquidity comes from the part } \\
\text { of "clearing capital" invested in securities (held in only } \\
\text { one bank which is also a CCP's member) and two } \\
\text { liquidity lines provided by the two same banks referred } \\
\text { above. }\end{array}$ \\
\hline & & $\begin{array}{l}\text { Also the liquidity resources are not adequate notably } \\
\text { taking into account that NOMX DM recently started } \\
\text { clearing repos, which can create higher liquidity needs } \\
\text { than the derivative products which have so far been } \\
\text { cleared. The liquidity management framework has not } \\
\text { been upgraded when repo clearing was introduced, } \\
\text { while the NOMX DM liquidity risk has consequently } \\
\text { risen. } \\
\text { It has to be noted that NOMX DM is contemplating to } \\
\text { put in place a new Collateral Management Service (see } \\
\text { recommendation 7) which would result in several } \\
\text { enhancements to the current set up. Notably NOMX } \\
\text { DM would then be in a position to access the cash } \\
\text { deposited as collateral and to invest that cash collateral } \\
\text { in liquid assets that, in case of need, may then be } \\
\text { repoed with the central bank to obtain liquidity. }\end{array}$ \\
\hline \multicolumn{3}{|l|}{ Default procedures } \\
\hline $\begin{array}{l}\text { 6. A CCP default procedures should be } \\
\text { clearly stated, and should ensure that the } \\
\text { CCP can take timely action to contain losses } \\
\text { and liquidity pressure and to continue } \\
\text { meeting its obligations. Key aspects of the } \\
\text { default procedures should be publicly } \\
\text { available. }\end{array}$ & $\mathrm{O}$ & $\begin{array}{l}\text { The default procedures are clearly described in the } \\
\text { R\&R and permit to close out or manage appropriately } \\
\text { the positions of the defaulting clearing members. The } \\
\text { structure of customer segregation under the agent } \\
\text { clearing model highly facilitates the transfer of } \\
\text { collateral and positions of end-customers in case of a } \\
\text { member's default. The legal framework gives a high } \\
\text { degree of assurance that the NOMX DM's decisions in } \\
\text { the event of default of a clearing member would not be } \\
\text { reversed. NOMX DM has an internal plan in place that } \\
\text { clearly delineates the responsibilities for managing } \\
\text { customers' positions in default and for drawing on } \\
\text { financial resources. Key aspects of NOMX DM default }\end{array}$ \\
\hline
\end{tabular}




\begin{tabular}{|c|c|c|}
\hline Responsibility & Grading & Comments \\
\hline & & $\begin{array}{l}\text { procedures are available to the public through the } \\
\text { publication of the } R \& R \text {. }\end{array}$ \\
\hline \multicolumn{3}{|l|}{ Custody and investment risk } \\
\hline $\begin{array}{l}\text { 1. A CCP should hold assets in a manner } \\
\text { whereby risk of loss or of delay in its access } \\
\text { to them is minimized. Assets invested by a } \\
\text { CCP should be held in instruments with } \\
\text { minimal credit, market and liquidity risks. }\end{array}$ & PO & $\begin{array}{l}\text { NOMX DM has no real time knowledge on the } \\
\text { composition of collateral collected as well as no ex } \\
\text { post information on it, except when it conducts a test } \\
\text { once in a year. NOMX DM relies on Custodian } \\
\text { Institutions, which are also CCP's members, for } \\
\text { collection of collateral, valuation, application of } \\
\text { haircuts, compliance with concentration limits. } \\
\text { Controls on Custodian Institutions are delegated to an } \\
\text { outside body which may conduct inspections. } \\
\text { Investments are made on high quality securities (AAA } \\
\text { Swedish government bonds). But the investment policy } \\
\text { is less strict since it allows investment in A rated } \\
\text { securities. }\end{array}$ \\
\hline \multicolumn{3}{|l|}{ Operational risk } \\
\hline $\begin{array}{l}\text { 2. A CCP should identify sources of } \\
\text { operational risk and minimize them through } \\
\text { the development of appropriate systems, } \\
\text { controls and procedures. Systems should be } \\
\text { reliable and secure, and have adequate, } \\
\text { scalable capacity. BCPs should allow for } \\
\text { timely recovery of operations and } \\
\text { fulfillment of a CCP's obligations. }\end{array}$ & $\mathrm{O}$ & $\begin{array}{l}\text { NOMX DM identifies and analyses source of } \\
\text { operational risks through a framework also } \\
\text { encompassing outsourced operations. NOMX DM has } \\
\text { two mirrored sites and a BCP in place which is } \\
\text { regularly tested. The operational risk is under the scope } \\
\text { of Internal Audit. }\end{array}$ \\
\hline \multicolumn{3}{|l|}{ Money settlements } \\
\hline $\begin{array}{l}\text { 3. A CCP should employ money } \\
\text { settlement arrangements that should } \\
\text { eliminate or strictly limit its settlement bank } \\
\text { risks, that is, its credit and liquidity risk } \\
\text { from the use of banks to effect money } \\
\text { settlements with its participants. Funds } \\
\text { transfers to a CCP should be final when } \\
\text { effected. }\end{array}$ & $\mathrm{O}$ & $\begin{array}{l}\text { NOMX DM uses the central bank model for SEK and } \\
\text { DKK which represent } 99 \text { percent of settlement flows. } \\
\text { Payments made and received by NOMX DM are } \\
\text { effected on its accounts with RB and Nationalbank. } \\
\text { Funds transfers to NOMX DM's accounts are final } \\
\text { when effected. Payments made and received through } \\
\text { commercial banks are negligible and not relevant from } \\
\text { a risk management perspective. }\end{array}$ \\
\hline \multicolumn{3}{|l|}{ Physical deliveries } \\
\hline $\begin{array}{l}\text { 4. A CCP should clearly state its } \\
\text { obligations with respect to physical } \\
\text { deliveries. The risks from these obligations } \\
\text { should be identified and managed. }\end{array}$ & $\mathrm{O}$ & $\begin{array}{l}\text { NOMX DM's R\&R clearly set its obligations with } \\
\text { respect to deliveries of securities. NOMX DM uses } \\
\text { securities settlement systems that ensure the DvP. } \\
\text { NOMX DM has not implemented a penalty regime in } \\
\text { case of late delivery while some new participants are a } \\
\text { source of late delivery. }\end{array}$ \\
\hline
\end{tabular}




\begin{tabular}{|c|c|c|}
\hline Responsibility & Grading & Comments \\
\hline \multicolumn{3}{|l|}{ Risks in links between CCPs } \\
\hline $\begin{array}{l}\text { 5. CCPs that establish links either cross- } \\
\text { border or domestically to clear trades should } \\
\text { evaluate the potential sources of risks that } \\
\text { can arise, and ensure that the risks are } \\
\text { managed prudently on an ongoing basis. } \\
\text { There should be a framework for } \\
\text { cooperation and coordination among the } \\
\text { relevant regulators and overseers. }\end{array}$ & & Not applicable. \\
\hline \multicolumn{3}{|l|}{ Efficiency } \\
\hline $\begin{array}{l}\text { 6. While maintaining safe and secure } \\
\text { operations, CCPs should be cost-effective in } \\
\text { meeting the requirements of participants. }\end{array}$ & $\mathrm{O}$ & $\begin{array}{l}\text { NOMX DM has in place the mechanisms to regularly } \\
\text { review its cost and pricing as well as its service levels } \\
\text { and operational reliability. NOMX DM also } \\
\text { benchmarks its costs and fees with other CCPs, but } \\
\text { considers that due to differences in the nature of the } \\
\text { services and markets, the results have to be considered } \\
\text { with caution. }\end{array}$ \\
\hline \multicolumn{3}{|l|}{ Governance } \\
\hline $\begin{array}{l}\text { 7. Governance arrangements for a CCP } \\
\text { should be clear and transparent to fulfill } \\
\text { public interest requirements and to support } \\
\text { the objectives of owners and participants. In } \\
\text { particular, they should promote the } \\
\text { effectiveness of a CCP's risk management } \\
\text { procedures. }\end{array}$ & $\mathrm{BO}$ & $\begin{array}{l}\text { Governance arrangements of NOMX DM are clearly } \\
\text { specified and information about them is publicly } \\
\text { available on the website. The governance arrangements } \\
\text { support robust risk management by a separation in the } \\
\text { reporting lines between risk management and other } \\
\text { operations. In both the Clearing risk committee and the } \\
\text { Default committee, the head of risk management has a } \\
\text { veto power. The Board and the management are } \\
\text { accountable for NOMX DM's performance. The } \\
\text { objectives include delivering sound risk management. } \\
\text { However, there is a lack of users' feedback and } \\
\text { involvement through consultative user groups. NOMX } \\
\text { DM does not sufficiently request feedback on its } \\
\text { clearing services from members on a multilateral basis. } \\
\text { Participants are not represented on NOMX STO Board } \\
\text { or through participant committees within NOMX DM } \\
\text { that would bring their specific perspectives and } \\
\text { interests. }\end{array}$ \\
\hline \multicolumn{3}{|l|}{ Transparency } \\
\hline $\begin{array}{l}\text { 8. A CCP should provide market } \\
\text { participants with sufficient information for } \\
\text { them to identify and evaluate accurately the }\end{array}$ & $\mathrm{O}$ & $\begin{array}{l}\text { NOMX DM discloses a wide range of information, } \\
\text { both in Swedish and in English, which its members can } \\
\text { use to evaluate the risks of using the CCP services. }\end{array}$ \\
\hline
\end{tabular}




\begin{tabular}{|c|c|c|}
\hline Responsibility & Grading & Comments \\
\hline \multicolumn{3}{|l|}{$\begin{array}{l}\text { costs and risks associated with using its } \\
\text { services. }\end{array}$} \\
\hline \multicolumn{3}{|l|}{ Regulation and oversight } \\
\hline $\begin{array}{l}\text { 9. A CCP should be subject to transparent } \\
\text { and effective regulation and oversight. In } \\
\text { both a domestic and an international context, } \\
\text { central banks and securities regulators } \\
\text { should co-operate with each other and with } \\
\text { other relevant authorities. }\end{array}$ & $\mathrm{BO}$ & $\begin{array}{l}\text { The legal basis for an effective regulation and oversight } \\
\text { exists. FI and RB have the ability and the resources to } \\
\text { carry out regulation and oversight activities effectively. } \\
\text { However authorities could have been more proactive } \\
\text { regarding NOMX DM collateral management system. } \\
\text { For years, the authorities have had knowledge of the }\end{array}$ \\
\hline & & $\begin{array}{l}\text { set up for collecting margin which is fully outsourced } \\
\text { to Custodian Institutions and which involves risks for } \\
\text { NOMX DM (see recommendation 7). They had } \\
\text { mentioned in their annual assessments that such set up } \\
\text { was a concern but they did not request or seek to } \\
\text { induce changes to that situation. } \\
\text { The responsibilities as well as roles and major policies } \\
\text { of FI and RB are clearly defined and publicly } \\
\text { disclosed. } \\
\text { FI and RB require NOMX DM to provide information } \\
\text { necessary for regulation and oversight. However, they } \\
\text { do not have a sufficient level of information and } \\
\text { understanding of the activities conducted by NOMX } \\
\text { COM which would be required by the spillover effects } \\
\text { this latter one could have on NOMX STO and notably } \\
\text { NOMX DM. } \\
\text { FI and RB cooperate with each other and with other } \\
\text { relevant authorities. However efficiency gains may be } \\
\text { reaped by more effective cooperation between both } \\
\text { national authorities and by adopting a more risk based } \\
\text { approach. The exact respective responsibilities } \\
\text { regarding NOMX COM, both in normal times and in } \\
\text { crisis situation, among Norwegian and Swedish } \\
\text { authorities is not fully clear among the concerned } \\
\text { authorities. The MOU on cross border financial } \\
\text { stability among MOF, central banks, and FSAs in } \\
\text { Nordic countries, signed in August } 2010 \text {, which } \\
\text { explicitly covers CCPs has not resulted so far in any of } \\
\text { the measures stipulated in the MOU. }\end{array}$ \\
\hline
\end{tabular}


Table 4. Key Recommendations

\begin{tabular}{|c|c|}
\hline $\begin{array}{c}\text { Reference } \\
\text { Recommendation }\end{array}$ & Recommended Action \\
\hline $\begin{array}{l}\text { Recommendation } 2 \text { : } \\
\text { Participation requirements }\end{array}$ & $\begin{array}{l}\text { NOMX DM should set participation requirements for direct pledge end } \\
\text { customers. It should be noted that NOMX DM has started a process for } \\
\text { possibly setting requirements for such end customers. }\end{array}$ \\
\hline $\begin{array}{l}\text { Recommendation 4: } \\
\text { Margin requirements }\end{array}$ & $\begin{array}{l}\text { NOMX DM should not accept bank guarantee as collateral due to the fact that } \\
\text { such collateral is not liquid and that providers of such guarantees are NOMX } \\
\text { DM's members. }\end{array}$ \\
\hline $\begin{array}{l}\text { Recommendation 5: } \\
\text { Financial resources }\end{array}$ & $\begin{array}{l}\text { NOMX DM should overhaul the complete structure on which its regulatory } \\
\text { capital is based and implement a more straightforward and fully funded } \\
\text { framework. } \\
\text { Two totally ring-fenced capital bases for both NOMX DM and NOMX COM } \\
\text { in order to face losses in case of default in stressed situations should be set up. } \\
\text { Based on the envisaged set up of a mutualized guarantee fund to fulfill likely } \\
\text { requirements set by EMIR, this should result in two separated guarantee funds } \\
\text { for NOMX DM and for NOMX COM being set up. } \\
\text { Swedish authorities should thoroughly analyze the advantages and drawbacks } \\
\text { of having trading activities and clearing activities currently being conducted } \\
\text { within the same legal entity, NOMX STO. For sake of clarity, clearing } \\
\text { activities could be isolated in a distinct legal entity. } \\
\text { NOMX DM should enhance its liquidity framework. It should ensure that the } \\
\text { collateral collected present a high degree of liquidity and consequently bank } \\
\text { guarantees should be excluded. NOMX DM should raise the number of its } \\
\text { liquidity providers (only two currently). NOMX DM should put in place the } \\
\text { operational set up so that it can use, in case of needs, the intraday liquidity } \\
\text { that may be provided by RB. Also it would be of interest for NOMX DM to } \\
\text { operationally implement the deposit facility that it can be provided with by } \\
\text { RB, so that in case of need (distressed market) that possibility could be } \\
\text { immediately used. }\end{array}$ \\
\hline $\begin{array}{l}\text { Recommendation } 7 \text { : } \\
\text { Custody and investment risks }\end{array}$ & $\begin{array}{l}\text { NOMX DM should completely overhaul its current custodian arrangements } \\
\text { and rely on CSDs. It should be noted that NOMX DM is in the process of } \\
\text { setting up a fully new arrangement to collect collateral by 2012, which based } \\
\text { on the draft project should apparently address the observed weaknesses. } \\
\text { NOMX DM should review its investment policy and analyze whether there is } \\
\text { a need to strengthen it through restricting investment to the highest rated } \\
\text { securities, for instance AAA securities as currently done in practice. }\end{array}$ \\
\hline $\begin{array}{l}\text { Recommendation 13: } \\
\text { Governance }\end{array}$ & $\begin{array}{l}\text { NOMX DM should enhance member's involvement in clearing activities } \\
\text { through their adequate representation, for instance through a formal advisory } \\
\text { committee. }\end{array}$ \\
\hline
\end{tabular}




\begin{tabular}{|l|l|}
\hline \multicolumn{1}{|c|}{ Reference } & \multicolumn{1}{|c|}{ Recommended Action } \\
\hline Recommendation 15: & $\begin{array}{l}\text { Swedish authorities should clarify in practical terms with Norwegian } \\
\text { authorities the exact sharing of responsibilities among themselves regarding } \\
\text { NOMX COM, both in normal times and in crisis situation, and consequently } \\
\text { adapt their supervision and oversight. }\end{array}$ \\
$\begin{array}{ll}\text { Swedish authorities should enhance their knowledge of activities conducted } \\
\text { by NOMX COM, due to the spillover effects this latter one could have on } \\
\text { NOMX STO and notably NOMX DM. }\end{array}$ \\
\hline \multirow{7}{*}{$\begin{array}{l}\text { The authorities should operationalize for clearing activities the MOU on cross } \\
\text { border financial stability among MOF, central banks and FSAs in Nordic } \\
\text { countries, signed in August 2010. } \\
\text { FI and RB should formalize the routines and procedures of their cooperation } \\
\text { in order to increase exchange of information, to possibly share or allocate } \\
\text { specific tasks among themselves, to enhance their common analysis capacity, } \\
\text { and to gain efficiency beneficial for both parties. As an example for } \\
\text { information sharing, this routine could comprise common reporting } \\
\text { requirements that would allow the authorities to get regular and frequent } \\
\text { updated data from NOMX DM. } \\
\text { Authorities should analyze whether an annual assessment is necessary or } \\
\text { whether a less frequent review could be contemplated combined with a more } \\
\text { risk based approach. } \\
\text { Authorities should strive to strengthen their staffing resources with skills in } \\
\text { quantitative analysis in order to be in a position to directly asses (and/or be } \\
\text { able to critically review reports which are ordered to external consultants) } \\
\text { quantitative models used to calculate margins and financial resources. }\end{array}$} \\
\hline
\end{tabular}

Table 5. Additional Recommendations

\begin{tabular}{|l|l|}
\hline \multicolumn{1}{|c|}{ Recommendation } & \multicolumn{1}{c|}{ Recommended Action } \\
\hline $\begin{array}{l}\text { Recommendation 1: } \\
\text { Legal risk }\end{array}$ & $\begin{array}{l}\text { FI should approve any substantial changes in the R\&R in order to ensure that } \\
\text { the rules stay consistent with the whole risk management framework. }\end{array}$ \\
\hline $\begin{array}{l}\text { Recommendation 10: } \\
\text { Physical deliveries }\end{array}$ & NOMX DM should implement a penalty system for failed delivery. \\
\hline Recommendation 12: & $\begin{array}{l}\text { The satisfaction survey conducted by NOMX DM every year should include } \\
\text { questions on clearing services. }\end{array}$ \\
\hline $\begin{array}{l}\text { Recommendation 15: } \\
\text { Regulation and oversight }\end{array}$ & $\begin{array}{l}\text { RB as an overseer should explore with central banks in Denmark, Finland and } \\
\text { Norway, whether they have an interest to participate in an oversight } \\
\text { arrangement for NOMX DM. }\end{array}$ \\
\hline
\end{tabular}




\section{Authorities' ReSPONSE TO THE ASSESSMENT}

18. The Swedish authorities welcome the detailed assessment of NASDAQ OMX Derivatives Markets carried out by the IMF. The recommendations are constructive and we look forward to using them in our supervisory and oversight processes. Work has already been initiated in response to many of the views expressed in the assessment and plans are being developed in order to analyze the remaining comments. The Swedish authorities have the following comments to the recommendations currently graded as not fully observed by IMF.

\section{Recommendation 2: Participation requirements}

19. The assessment correctly states that a process for setting specific requirements for direct pledge clients is under way. The Swedish authorities agree with the recommendation and are following the progress and development closely.

\section{Recommendation 4: Margin requirements}

20. NASDAQ OMX Derivatives Markets (NOMX DM) currently accepts bank guarantees as collateral for clearing, which according to the assessment is undesirable as they are illiquid and rely on institutions which are also members of NOMX DM. The recommendation is sensible and the Swedish authorities will enter into discussions with NOMX DM about the use of bank guarantees as accepted collateral.

\section{Recommendation 5: Financial resources}

21. In order to adjust to coming European regulation, NOMX DM is running a project to introduce a default fund. The Swedish authorities follow this project and will give recommendations to NOMX DM on how to set up its financial resources in the future. Furthermore, a review of the liquidity framework is also taking place. The Swedish authorities will further consider the recommendation given regarding legal separation of clearing and trading.

\section{Recommendation 7: Custody and investment risks}

22. NOMX DM is, as expressed in the assessment, currently in the middle of a project aiming to introduce a new collateral management system in 2012. Swedish authorities are monitoring the progress, which will address the current shortcomings.

\section{Recommendation 13: Governance}

23. Swedish authorities will, in line with the assessment, engage NOMX DM to ensure that members are appropriately involved in the governance, also when it comes to the clearing activities. Further involvement from the members will most likely also come natural due to other developments within NOMX DM. 
Recommendation 15: Regulation and oversight

24. Relevant points were brought up in the assessment, and the comments are taken seriously by the Swedish authorities. 